\title{
Hydrogeology and Ground-Water Quality at a Land Reclamation Site, Neshaminy State Park, Pennsylvania
}

U.S. GEOLOGICAL SURVEY

Water-Resources Investigations Report 86-4164

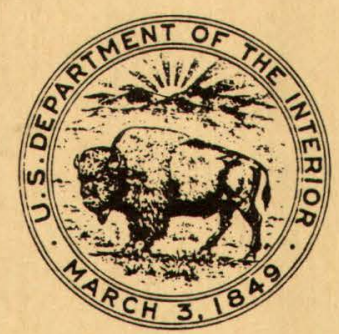


HYDROGEOLOGY AND GROUND-WATER QUALITY AT A LAND RECLAMATION SITE, NESHAMINY STATE PARK, PENNSYlvANIA

By Roy S. Blickwedel and Jeff H. Linn

U.S. GEOLOGICAL SURVEY

Water-Resources Investigations Report 86-4164

Prepared in cooperation with

CITY OF PHILADELPHIA and the

PENNSYLVANIA BUREAU OF STATE PARKS

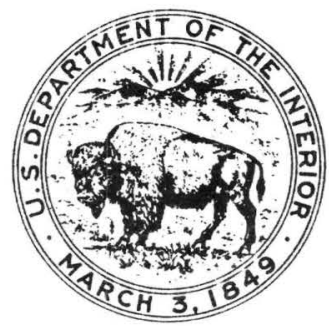

Harrisburg, Pennsylvania 


\section{DEPARTMENT OF THE INTERIOR \\ DONALD PAUL HODEL, Secretary}

\section{U.S. GEOLOGICAL SURVEY}

Dallas L. Peck, Di rector

For additional information write to:

District Chief

U.S. Geological Survey, WRD

P.0. Box 1107

Harrisburg, Pennsylvania 17108-1107
Copies of this report

can be purchased from:

U.S. Geological Survey

Books and Open-file Reports Section Federal Center

Box 25425

Denver, Colorado 80225 


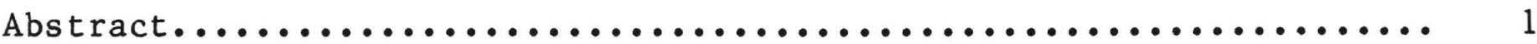

Introduction........................................

Background..........................................

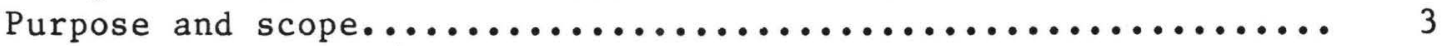

Site description......................................

Location and physiography.............................

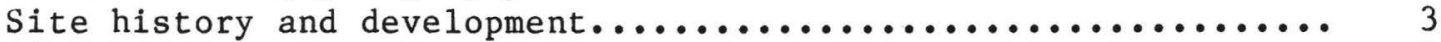

Sludge properties................................... 6

Precipitation......................................

Hyd rogeology ............................................. 11

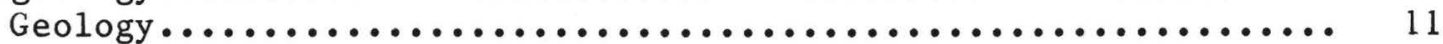

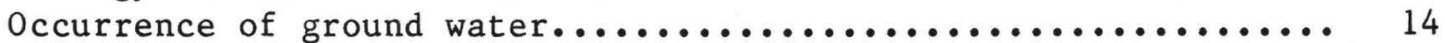

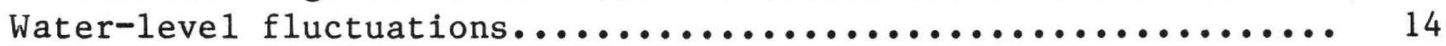

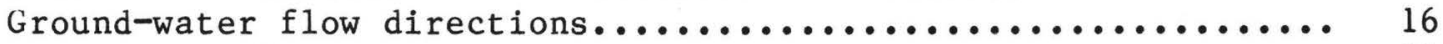

Ground-water quality..................................... 20

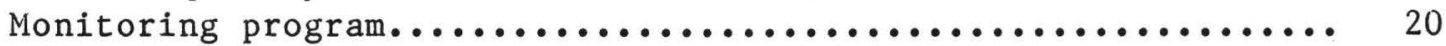

Chemical and physical characteristics...................... 21

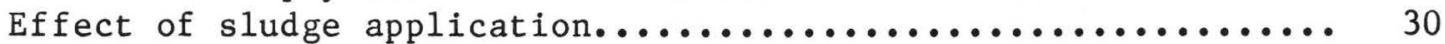

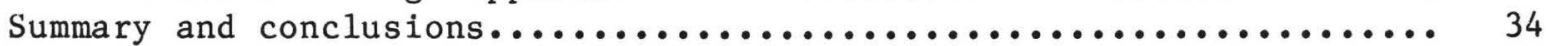

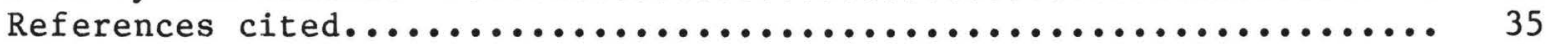

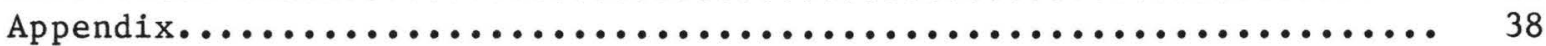

\section{ILLUSTRATIONS}

Figure 1.--Map showing location of Neshaminy State Park and

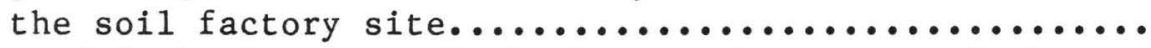

2.--Map of Neshaminy State Park showing the extent of the hydraulic fill, soil factory boundary, and ground-water

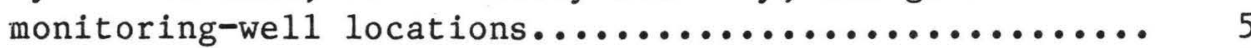

3.--Sludge-disposal flow chart....................... 6

4.--Bar chart comparing precipitation at Neshaminy State Park with precipitation at Neshaminy Falls.......... 10

5.--Generalized geologic section $\mathrm{A}^{-\mathrm{A}^{\prime}}$ at Neshaminy State

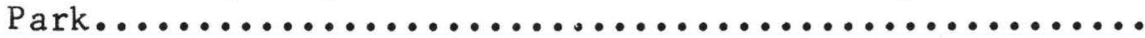

6.--Generalized geologic section $B-B$ ' at Neshaminy State

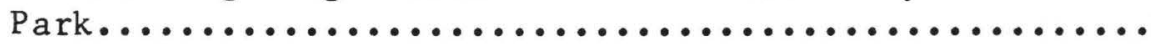
7-8.--Hydrographs of water levels in wells screened in the:

7.--Trenton grave1................................

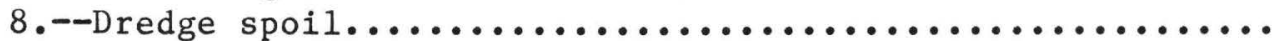
9-11.--Map showing potentiometric surface of the Trenton grave1, November-December 1984:

9.--at low tide...................................

$10 .-$-at mean tide..................................

11.--at high tide..................................

12.--Graph showing specific conductance of ground water and precipitation in 5-day increments, October 1983 to March 1985.

\section{6}




\section{ILLUSTRATIONS--Continued}

Page

Figure 13.--Graph showing $\mathrm{pH}$ of ground water, October 1983 to

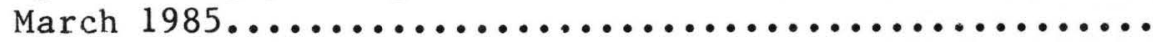

14-19.--Graphs showing:

14.--dissolved organic carbon in ground water,

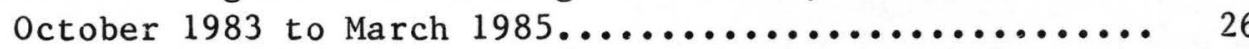

15.--dissolved sulfate in ground water, October

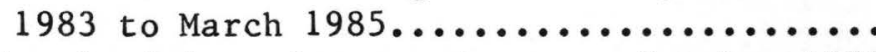

16.--dissolved iron in ground water, October 1983

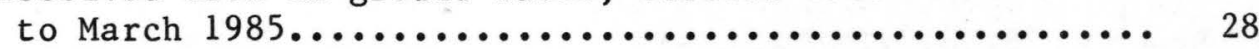

17.--dissolved ammonium in ground water, October

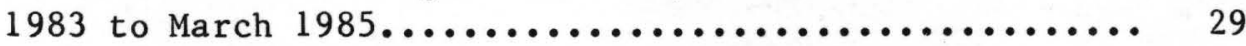

18.--dissolved organic nitrogen in ground water,

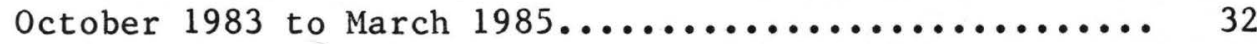

19.--dissolved manganese in ground water, October

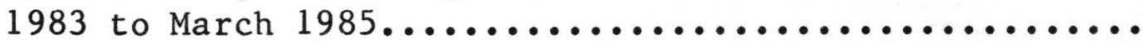

\section{TABLES}

Table 1.--Chemical characteristics of unscreened compost........ 7

2.--Concentrations of heavy metals in the dredge spoils, compost, and spoils-compost mixture, $1980-82 \ldots \ldots \ldots \ldots . . .8$

3.--Monthly precipitation at Neshaminy State Park and Neshaminy Falls.............................. 9 9

4.--Summary of well-construction data.................. 20

5.--Selected chemical analyses of ground water by the

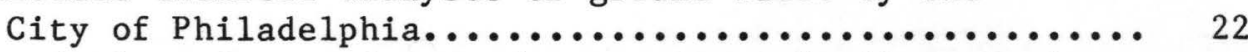

6.--Chemical analyses of ground water for volatile organic compounds...............................

Appendix--Chemical analyses of ground water for major ions and

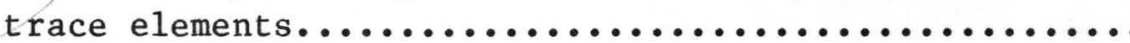


For the convenience of readers who prefer metric (International System) units rather than the inch-pound units used in this report, the following conversion factors may be used:

Multiply Inch-Pound Unit

Length

inch (in.)

foot (ft)

mile (mi)

foot per mile ( $\mathrm{ft} / \mathrm{mi}$ )

0.1894

Area

acre

cubic yard $\left(\mathrm{yd}^{3}\right)$
ton

$\underline{\text { Transmissivity }}$

foot squared per day $\left(f t^{2} / d\right)$
$\underline{B y}$

Mass

0.9072

To Obtain Metric Unit

millimeter (mm)

meter (m)

kilometer $(\mathrm{km})$

meter per kilometer $(\mathrm{m} / \mathrm{km})$

Volume

0.7646

cubic meter $\left(\mathrm{m}^{3}\right)$

square kilometer $\left(\mathrm{km}^{2}\right)$

metric ton

0.01242 meter squared per day $\left(\mathrm{m}^{2} / \mathrm{d}\right)$

Sea leve1: In this report "sea level" refers to the National Geodetic Vertical Datum of 1929 (NGVD of 1929)--a geodetic datum derived from a general adjustment of the first-order level nets of both the United States and Canada, formerly called "Mean Sea Level of 1929." 

HYDROGEOLOGY AND GROUND-WATER QUALITY AT A

LAND RECLAMATION SITE, NESHAMINY

STATE PARK, PENNSYLVANIA

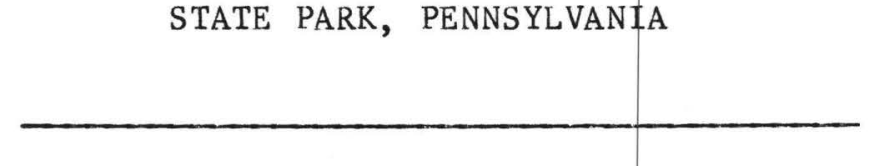

by Roy S. Blickwede1 and Jeff H. Linn

\begin{abstract}
At Neshaminy State Park, the most important aquifer is the informally named "Trenton gravel" of Pleistocene age, which consists of poorly sorted sand and grave1. This is underlain by less permeable crystalline rock that limits the downward movement of water. Up to 5 feet of Holocene (or perhaps Pleistocene) alluvium consisting of clay and silt was deposited above the Trenton gravel, but much of the surficial material is dredge spoil, mostly sand and silt from the Delaware River.

Normally, ground water discharges to the Delaware River and Neshaminy Creek. However, because the Trenton gravel is confined by the alluvium and is hydraulically connected to the Delaware River throughout its entire thickness due to channel dredging, hydraulic-head variations in the river are readily transmitted to wells. Thus, flow is toward the Delaware River and Neshaminy Creek at low tide, but the river and creek recharge the aquifer as the tide rises.

In September 1981 and October 1983, infertile dredge spoil from the Delaware River at Neshaminy State Park was mixed with composted sewage sludge and seeded to grasses to produce a soil product that has not adversely affected ground-water quality as of March 1985. Analyses for pH, specific conductance, nutrients, and heavy metals in ground water at the beginning of the study indicate that the chemistry of the ground water in the dredge spoil at the site differs from that in the Trenton gravel.

Analyses of ground-water samples collected after the first two sludge applications (120 tons per acre and 450 tons per acre), indicate that no significant change occured in the chemistry of the samples from the Trenton gravel, whereas organic nitrogen increased temporarily in ground water from the dredge spoil 6 months after the larger of the two sludge applications, but quickly returned to background levels. The lack of chemical change with time in the ground water implies either that little of the more than 100 inches of precipitation that fell from April 1983 through March 1985 reached the water table or, more likely, that a mechanism exists beneath the soilfactory site that retards or prevents the downward migration of contaminants.
\end{abstract}




\section{Background}

Neshaminy State Park is situated on a 330-acre site, 80 acres of which has been made from hydraulic-dredge spoils. This material has little moisture-holding capacity or fertility for plant growth and, consequently, provides little recreational value to the park. Because plant propagation plays a major role in the park's programmed development, the concept of a soil factory was developed. This resulted in a project between the City of Philadelphia and the Pennsylvania Bureau of State Parks to produce an environmentally safe, productive plant growth medium suitable for use in landscaping Neshaminy State Park. The mutual benefits derived from reclaiming a desolate land area, while providing a means of sewage sludge disposal, could be significant if the demonstration soil-manufacturing project does not have adverse environmental impacts.

Although many studies have been concerned with the effects of sewage sludge on soil, there does not appear to be any consensus on the fate of contaminants once applied. In some studies, heavy metals remained fixed (Sommers and others, 1979; Emmerich and others, 1982). However, in other studies, the movement of heavy metals downward in the soil profile has been reported (Boswe11, 1975; Sidle and Kardos, 1977). In general, dissolved solids, sodium, chloride, and nitrate appeared to be the best indicators of changes in ground-water chemistry following sludge application (Higgins, 1984; Robson, 1976).

Emmerich and others (1982) suggest that the lack of consistent movement of metals in sludge-treated soils may reflect differences in soil $\mathrm{pH}$ or the relatively short duration of study. A soil-pH conducive to the mobilization of metals occurs as the sludge material undergoes nitrification. Therefore, the application of lime or the presence of natural pH-stabilizing compounds in some soils mitigates metals transport. Although reductions in soil $\mathrm{pH}$ are common where the buffering capacity is low, a subsequent lack of metals leaching also was attributed to the high cation-exchange capacity of some soils (Higgins, 1984). A few metals, such as nickel and lead, may become associated with insoluble silicate minerals or converted into silicate phases after land application, thus preventing significant movement (Cao and others, 1984 ).

Sludge-disposal sites impact the environment in different ways because of the differences in siudge-disposal methods, physical settings, and waste character. Kam (1978) and Higgins (1984) note the importance of sludgeapplication rates on contaminant release. Kam (1978) also demonstrated that increases in precipitation and ground-water recharge that occur during cool, wet months cause increases in specific conductance, ch1oride concentration, and nitrate concentration in ground-water samples downgradient from a sludgeapplication site. In a study by Sylvester (1982), local pedologic and geologic characteristics were the main determinants of ground-water quality at some sites despite the application of effluent from wastewater-treatment plants. 
This report describes the results of a study conducted from February 1983 through September 1985 to determine possible effects of the soil-manufacturing project on ground-water quality. The hydrogeology of the study area is presented to provide background information for discussions of ground-water quality. Five monitoring wells were installed, and monthly ground-water samples were analyzed for pH, specific conductance, nutrients, common dissolved constituents and heavy metals for 18 months. The potential for developing similar sludge-disposal projects is evaluated from a ground-water-quality perspective. The study was done by the U.S. Geological Survey in cooperation with the City of Philadelphia and the Pennsylvania Bureau of State Parks.

\section{SITE DESCRIPTION}

\section{Location and Physiography}

Neshaminy State Park is in Bensalem Township, Bucks County, Pennsylvania, at the confluence of Neshaminy Creek and the Delaware River (fig. 1). The park lies within the Atlantic Coastal Plain physiographic province and is characterized by gently dipping, unconsolidated deposits of sand, gravel, and clay that unconformably overlie a southeastward-dipping crystalline basement. A 10-acre plot approximately 1,000 feet from the Delaware River is presently being used as the soil-factory site. Elevations generally range from 0 to 20 feet above sea level. The Delaware River is estuarine at the park with tidal variations of about 6 feet.

\section{Site History and Development}

Hydraulic-dredge spoils from a marina and from a section of the commercial shipping channel of the Delaware River were deposited on an 80 -acre site within the park (fig. 2). No dredge spoil has been deposited on the west side of Neshaminy Creek since the marina was dredged in 1974. The spoil was placed in the area designated hydraulic fill settling basin on figure 2, However, because periodic redredging is needed, the park may be used again to dispose of the material.

Three thicknesses of sludge (2, 3, and 4 inches) were applied in September 1981 on a 4.2-acre test plot to appraise the best sludge dredge-spoil mixture for optimal vegetative growth. A sewage sludge volume of $1,692 \mathrm{yd}^{3}$ (507 tons) was used for the initial phase of the project. This phase was terminated in September 1983, when a 6-inch deep mixture of sludge, dredge-spoil, and grass (now called top soil) was removed from the soil-factory site and used for landscaping in the soil emplacement site (fig. 2). The test area was then expanded to a 10-acre production facility in October 1983, to test the effects of larger amounts of sewage-sludge application. Lime was applied at 2 tons per acre to maintain a soil pH of at least 6.5. This second phase was used to measure the effect of 8 inches of sewage sludge mixed with 8 inches of dredged spoils on ground-water quality. This mixture totaled 11,950 $\mathrm{yd}^{3}(4,500$ tons $)$ of sewage sludge in a nearly equal volume of dredge spoil. 


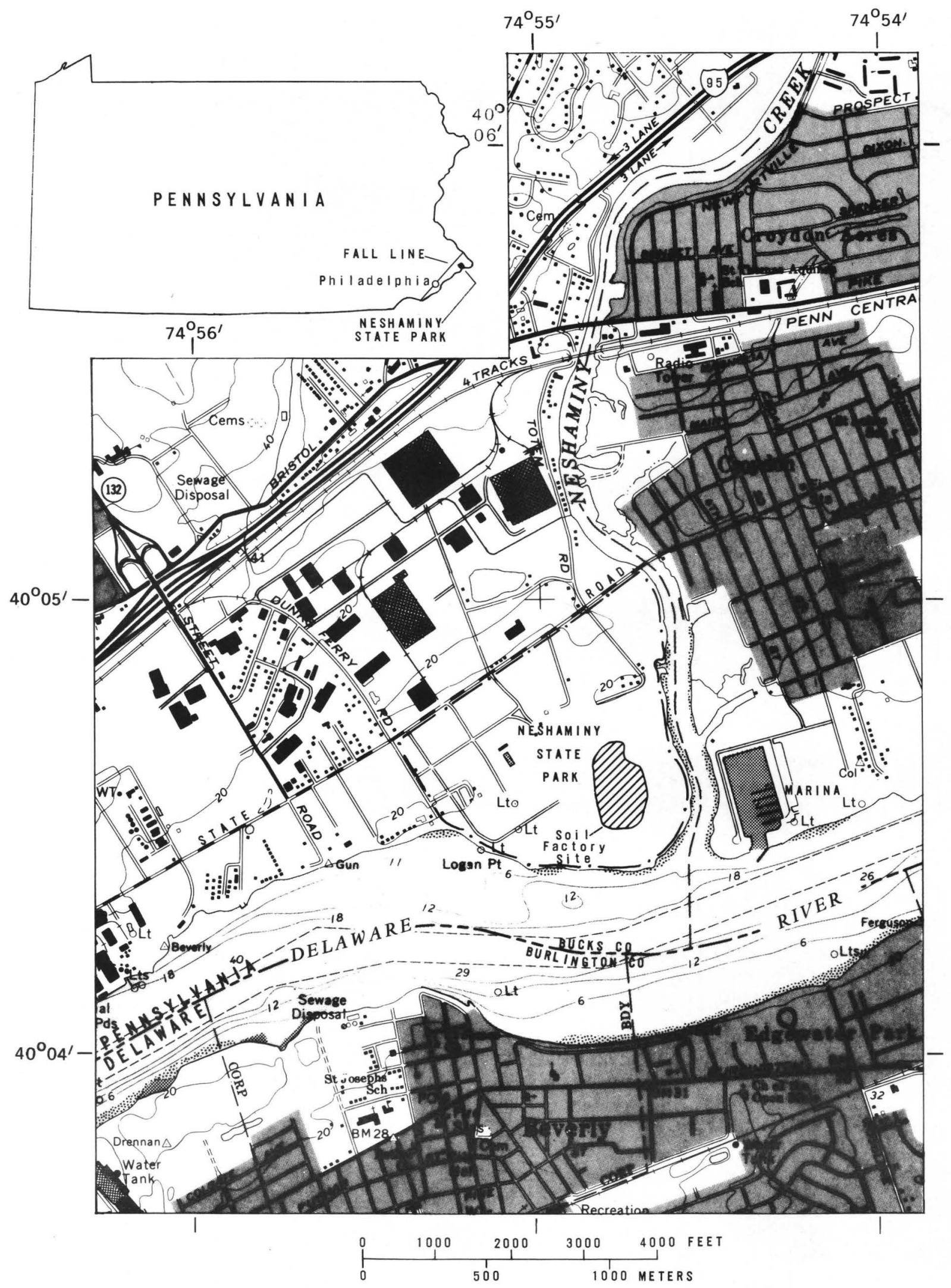

Figure 1.-Location of Neshaminy State Park and the soil-factory site. 


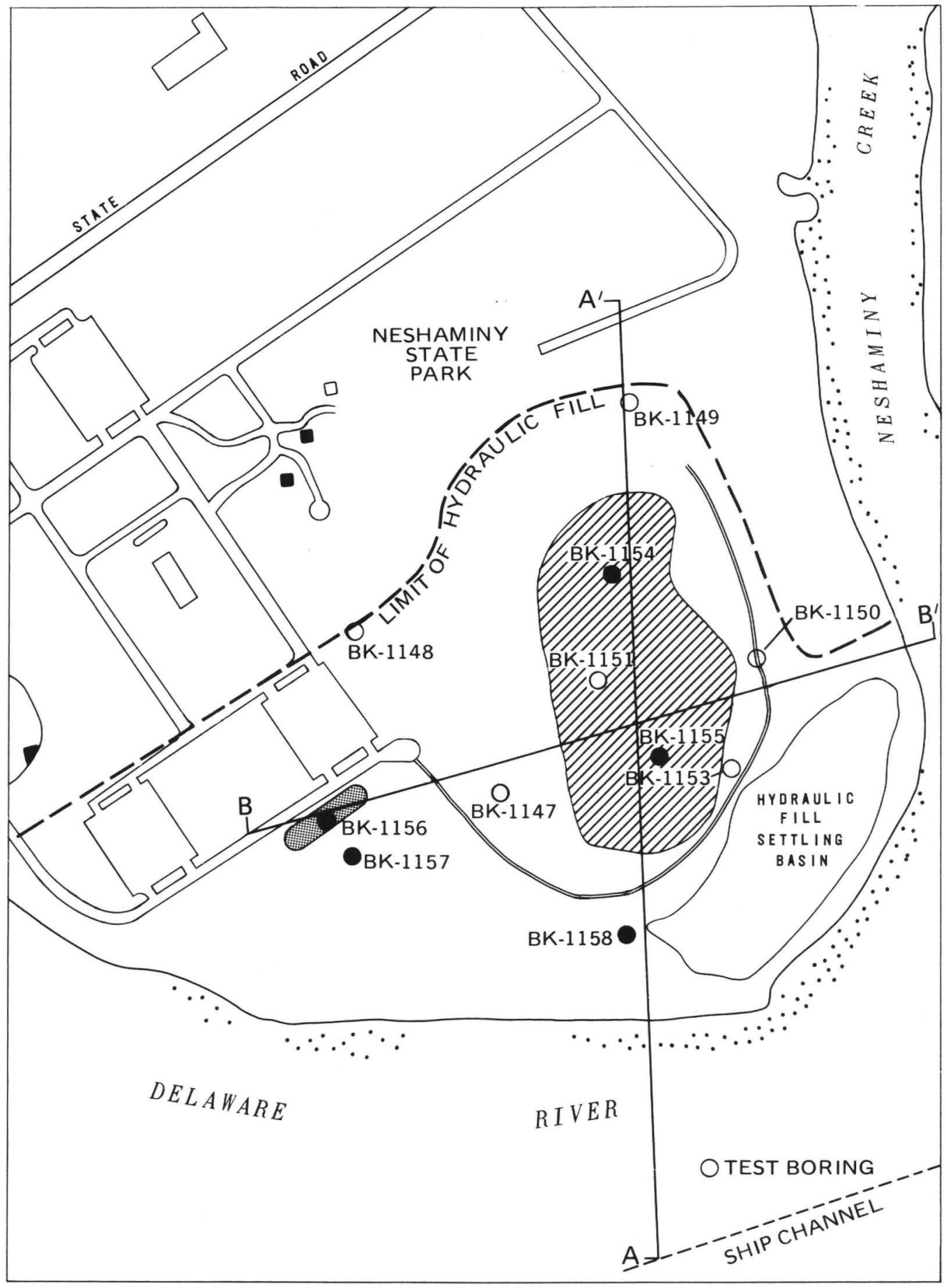

$$
\begin{array}{cccc}
\stackrel{0}{0} \quad 200 \quad 400 \quad 600 & 800 \text { FEET } \\
0 & 100 \quad 200 \text { METERS } \\
\text { EXPLANATION }
\end{array}
$$

$\therefore \therefore \therefore$ Tital flats

Approximate area of soil-factory site

O

Existing wells

New wells

Figure 2.--Neshaminy State Park showing the extent of the hydraulic fill soil-factory boundary, and ground-water monitoring-well locations. 
Treatment of sewage sludge by the Philadelphia Water Department Sludge Management Unit is diagrammed in figure 3. The sludge first undergoes anaerobic digestion followed by dewatering. Wood chips are then mixed with dewatered sludge and the mixture is subjected to forced aeration (composting) for about 3 weeks. When the biological decomposition of the organic fraction decreases (as indicated by the internal temperatures), the material is moved to a storage area and is cured for 30 days.

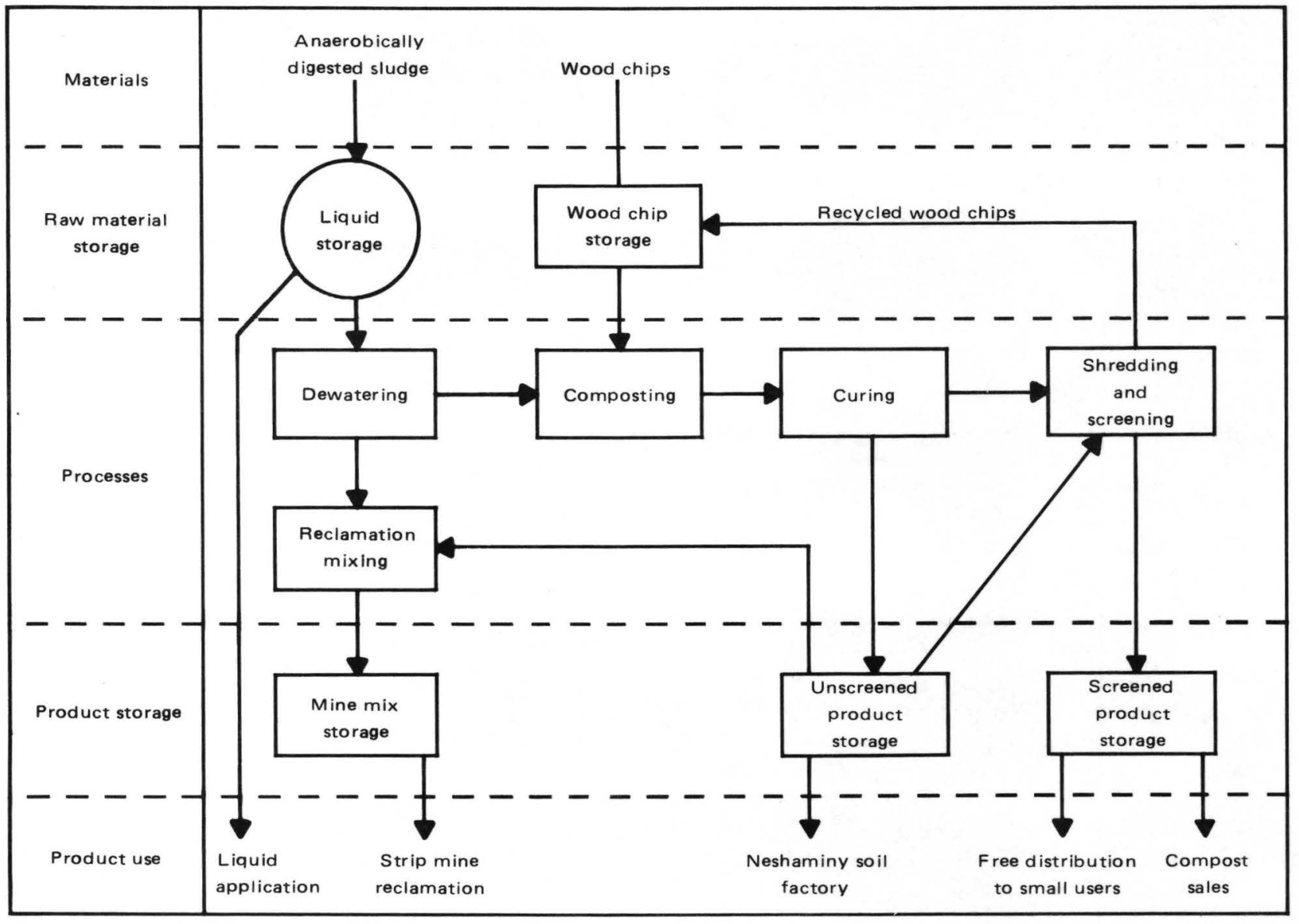

Figure 3.-Sludge-disposal flow chart.

The average chemical composition of composted sludge samples is listed in table 1. The 1980 average is for samples collected at the composting plant, whereas the 1981 and 1983 averages are for samples collected as the compost was delivered to the 4.2-acre test plot and the 10-acre production plot. Total Kjeldah1 nitrogen was somewhat higher in 1983 than in 1981, whereas metal concentrations generally were lower in 1983.

Heavy-metals concentrations in the dredge spoil, compost, and soilcompost mixtures for each of the three application rates are given in table 2 for the 4.2-acre test plot. As expected, the metal concentrations in the mixture are intermediate between that of the fill and the compost. However, the ratios of concentrations in the compost to those of the mixtures differ for different metals. 


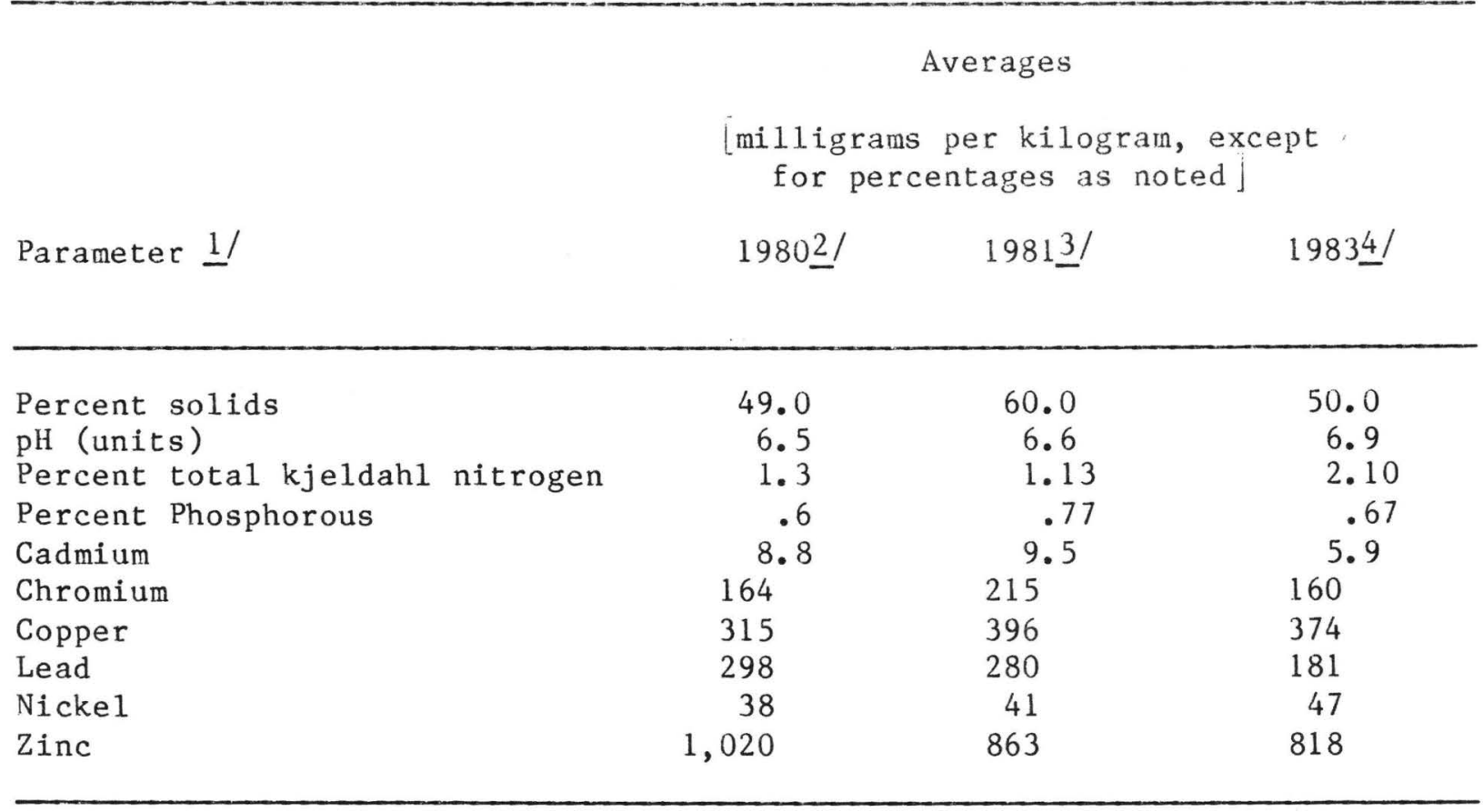

\section{1/ Source of data - AD+SOIL SYSTEMS Inc.*}

2/ Samples were collected at compost piles at the Southwest Treatment P1ant, Philadelphia, Pennsylvania. Thirty-two samples were collected from 32 separate piles, January-February 1980; and 26 samples were composited from 145 piles, February-September 1980.

3/ Samples were collected from each truck that delivered material for the Neshaminy Soil Factory in October 1981. Samples were composited into a total of eight daily samples.

4/ Average of compost samples collected from October 17-0ctober 31, 1983.

*Use of firm or brand names in this report is for identification purposes only and does not constitute endorsement by the U.S. Geological Survey. 
Table 2.--Concentrations of heavy metals in the dredge spoils, compost, and spoils-compost mixture, 1980-82

[Concentrations in milligrams per kilogram;

a dash indicates no data]

\begin{tabular}{lcccrrr}
\hline Material & Cadmium & Chromium & Copper & Lead & Nickel & Zinc \\
\hline Dredge spoil1/ & 0.06 & - & 4 & 6 & 6 & 31 \\
Compost (1981) & 9.5 & 215 & 396 & 280 & 41 & 863 \\
2-inch mixture (1982) & 1. & 66 & 42 & 55 & 16 & 154 \\
3-inch mixture (1982) & 1.5 & 52 & 35 & 46 & 16 & 130 \\
4-inch mixture (1982) & 1.5 & 68 & 47 & 46 & 16 & 186 \\
\hline
\end{tabular}

Source - Pennsylvania Department of Environmental Resources, Bureau of State Parks, written commun., 1985.

1/ Mean of one sample in 1980 and one sample in 1981.

\section{$\underline{\text { Precipitation }}$}

A nonrecording rain gage was installed at Neshaminy State Park in April 1983. Daily precipitation was measured by Bureau of State Parks personnel. Monthly totals are listed in table 3, as are monthly precipitation amounts and departures from normal precipitation at the National Oceanic and Atmospheric Administration's Neshaminy Falls observation station near the park. Precipitation totals for the period April 1983 through March 1985, are nearly identical for the two gages. Monthly precipitation at the park is compared to normal month1y precipitation (1951-80) at Neshaminy Fa11s in figure 4.

Comparison of monthly data at the park to normal monthly precipitation at the Neshaminy Falls station shows that above-normal precipitation fell during the first year of soil-factory operation. Rainfall was less than normal during the last few months of the ground-water-monitoring program. Precipitation for the entire period was slightly (6 percent) above normal. 
Table 3.--Monthly precipitation at Neshaminy State Park and Neshaminy Falls [Units in inches]

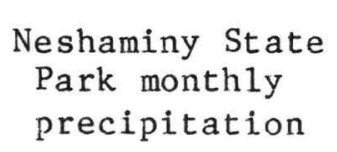

Neshaminy State

precipitation

\author{
Neshaminy Fa11s $\underline{1 /}$ \\ monthly \\ precipitation
}

Departures
from norma1
$(1951-80)$ at

Neshaminy Fa11s

1983

$\begin{array}{llll}\text { Apri1 } & 9.00 & 9.40 & +5.60 \\ \text { May } & 7.19 & 7.23 & +3.37 \\ \text { June } & 4.55 & 3.57 & -.08 \\ \text { Ju1y } & 1.92 & 1.10 & -3.82 \\ \text { August } & 2.53 & 2.36 & -2.83 \\ \text { September } & 4.01 & 2.95 & -1.15 \\ \text { October } & 4.01 & 4.71 & +1.35 \\ \text { November } & 6.132 / & 7.03 & +3.15 \\ \text { December } & 7.052 / & 8.02 & +4.28\end{array}$

1984

$\begin{array}{lrrr}\text { January } & 1.71 & 1.84 & -1.53 \\ \text { February } & 3.36 & 3.73 & +.63 \\ \text { March } & 5.44 & 5.25 & +.87 \\ \text { Apri1 } & 4.76 & 3.72 & -.08 \\ \text { May } & 8.00 & 8.39 & +4.33 \\ \text { June } & 2.55 & 3.57 & -.08 \\ \text { Ju1y } & 7.44 & 10.33 & +5.41 \\ \text { August } & 4.20 & 2.88 & -2.31 \\ \text { September } & 2.32 & 1.59 & -2.51 \\ \text { October } & 4.86 & 2.50 & -.86 \\ \text { November } & 1.98 & 2.09 & -1.79 \\ \text { December } & 2.60 & 2.74 & \end{array}$

1985

January

February

March

TOTAL
.82

2.53

1.65

100.61
1.09

2.43

2.01

100.53
$-2.28$

$-.67$

$\underline{-2.37}$

$+5.83$

1/ Compiled from U.S. Department of Commerce, National Oceanic and Atmospheric Administration.

2/ Daily values for November 23 through December 5 were estimated. 


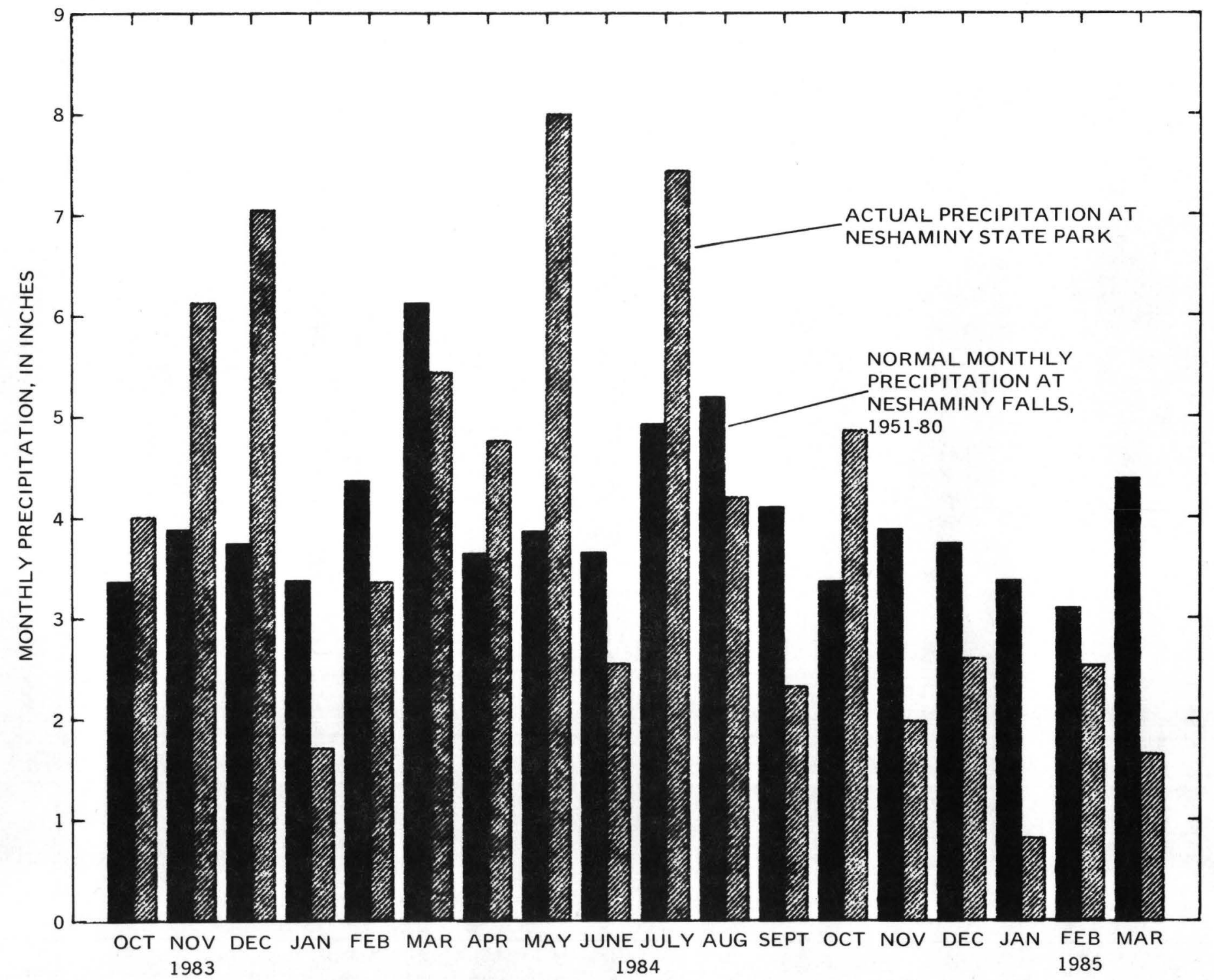

Figure 4.-Comparison of precipitation at Neshaminy State Park with precipitation at Neshaminy Falls. 
$\underline{\text { Geology }}$

Neshaminy State Park is situated approximately 1 mile southeast of the contact between Coastal Plain sediments and crystalline basement rocks. This contact is referred to as the Fall Line (fig. 1). Southeast of the Fal1 Line, unconsolidated clastic sediments form a wedge-shaped body that overlies the southeastward-dipping crystalline bedrock surface. The unconsolidated sediments thin updip to the northwest and pinch out along the Fal1 Line. The geology and ground-water resources of the region were discussed by Greenman (1955) and Greenman and others (1961).

The only naturally occurring unconsolidated deposits at Neshaminy State Park are poorly sorted sand and gravel deposited as glacial outwash during Pleistocene time. These deposits are informally named the "Trenton gravel" (Owens and Minard, 1979).

The Trenton gravel is underlain by the Wissahickon Formation of latest proterozoic and early paleozoic age. The upper few feet of this crystalline bedrock commonly weathers to a residual clay. The clayey material, termed saprolite, was encountered at a depth of $45 \mathrm{feet}$ (33 feet below sea level) in we11 BK-1147. A test boring drilled in the channel of the Delaware River encountered bedrock at 35 feet below sea level (see fig. 2 for location). Although the regional dip of the bedrock surface is approximately 60 feet per mile to the southeast (Zapecza, 1984), the bedrock surface appears to have only a slight southeast dip in the immediate area.

Up to 5 feet of Holocene (or perhaps Pleistocene) alluvium consisting of dark gray clay and silt was deposited above the Trenton grave1, but much of the surficial material in the park is fill. The fill, characteristically a fine-grained micaceous sand and silt with some gravel and locally, lenses of clay, was obtained from dredging the Delaware River and Neshaminy Park marina. Generalized geologic sections at the State park are presented in figures 5 and 6 . Al1 of the wells and well screens except BK-1148, are shown on the sections. 


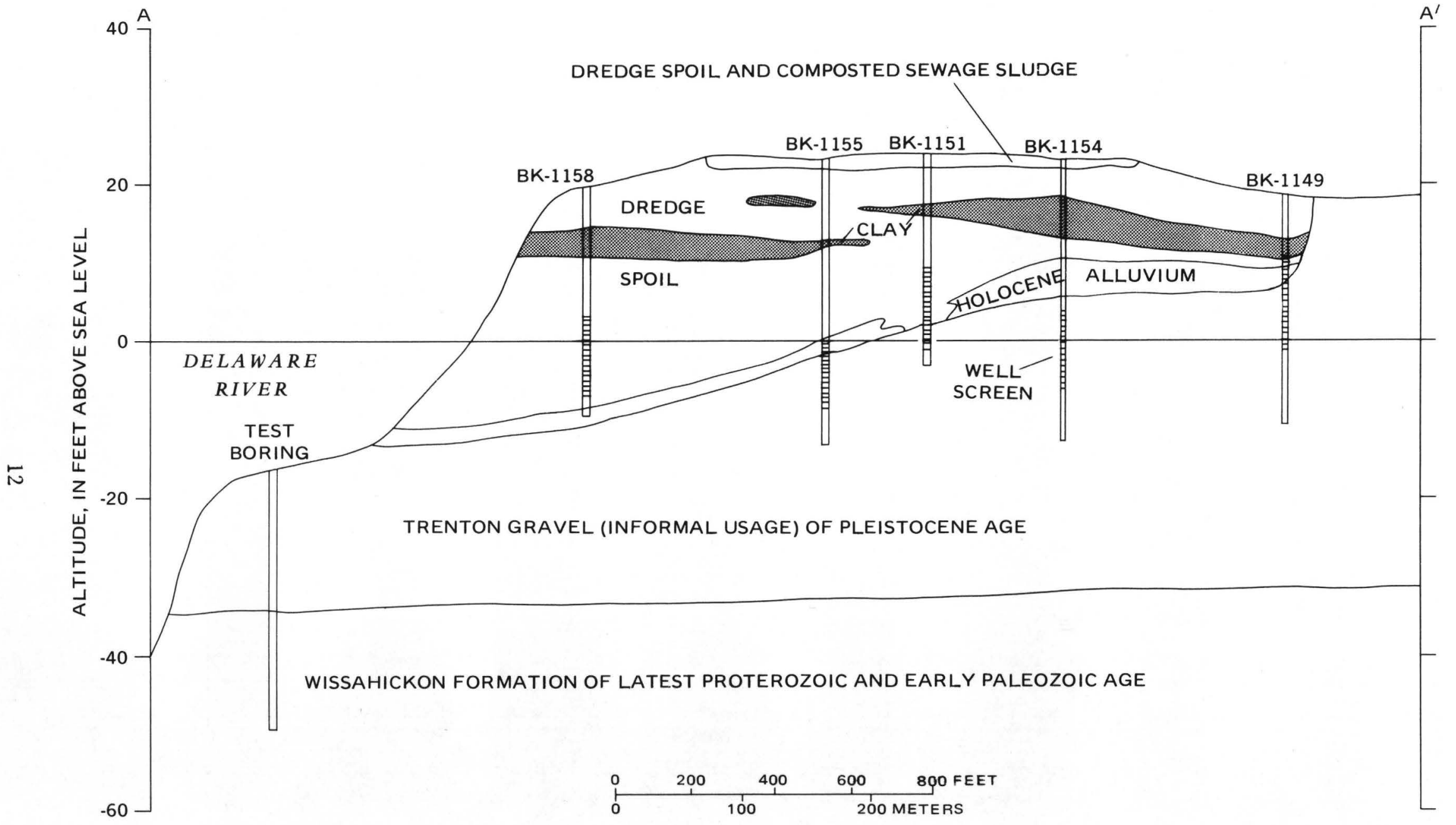

Figure 5.-Generalized geologic section $A-A^{\prime}$ at Neshaminy State Park. (See fig. 2 for location.) 

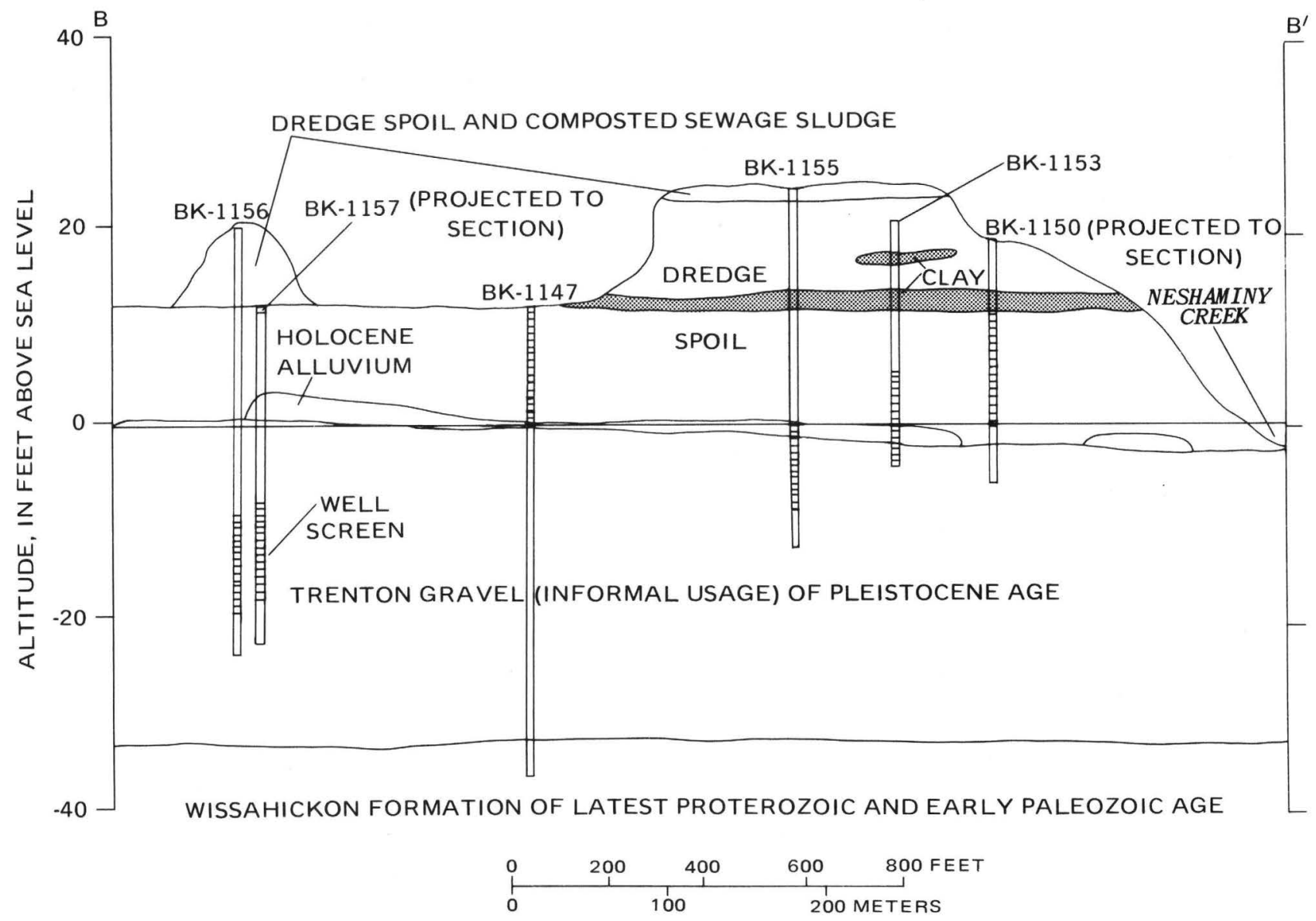

Figure 6.-Generalized geologic section B-B' at Neshaminy State Park. (See fig. 2 for location.) 
Ground water in the crystalline basement rocks was never extensively developed in the Pennsylvania Coastal Plain because larger and more readily available supplies can be obtained from the unconsolidated sediments. Generally, the crystalline rock is overlain by a residual clay layer that acts to confine it from the overlying sediments. Where the residual clay layer is absent, the hydraulic head in the crystalline rock is the same as that in the overlying sand and gravel. Therefore, the units are locally interconnected hydraulically, but the crystalline rock limits the downward movement of water from the more permeable Coastal Plain sediments. In nearby Philadelphia, average and median specific capacities of 103 we $11 \mathrm{~s}$ in the crystalline rock were 1.6 (gal/min)/ft (gallons per minute per foot) and 0.54 (gal/min)/ft, respectively. Specific capacities of 80 percent of the 103 wells exceed 0.13 (gal/min)/ft, whereas only 10 percent of them have specific capacities in excess of 3.2 (gal/min)/ft (G. N. Paulachok, U.S. Geological Survey, written commun., 1985). The specific capacity for 30 wells tapping the Trenton gravel ranged from 2 to 65 (gal/min)/ft, and averaged 21 (gal/min)/ft (Greenman and others, 1961).

Ground water in the sand and gravel is almost everywhere under watertable conditions. Locally, artesian conditions prevail where sufficiently thick deposits of Holocene alluvium overlie the coarse sediments.

\section{Water-leve1 Fluctuations}

Ground-water flow at the park is complicated by tidal fluctuations in the Delaware River. Norma11y, ground water discharges to the Delaware River and to Neshaminy Creek. Because ground-water levels fluctuate in response to tide cycles, however, the direction of ground-water flow changes cyclically also.

Water-level recorders were placed on the wells to observe the tidal fluctuations exhibited in ground water. In general, the tides exert a stronger influence on water levels in the wells close to the Delaware River than in those far away (fig. 7). We11 BK-1154 is furthest from the river and the average tidal fluctuation is less than 0.3 feet. We 11 s BK-1156, BK-1157, and BK-1155 fluctuate about 1.6 feet, 1.9 feet, and 1.95 feet, respectively (see fig. 2 or 9 for well locations).

Some of the wells do not respond in the typical manner, because they are not open to materials hydraulically connected to the Delaware River (fig. 8). We11s BK-1147, BK-1153, and BK-1158 show little tidal influence. These wells are screened in the dredge spoil above the low permeability silts and clays deposited as Holocene alluvium, preventing a good hydraulic connection to the Delaware River. We11 BK-1153 exhibits some tidal influence, but much less than would be expected from a well this close to the river. The well is mostly screened in the dredge spoil, but the screen extends a foot or two into the Trenton gravel. The Trenton gravel is hydraulically connected to the Delaware River throughout its entire thickness because of the channe1dredging operations. 

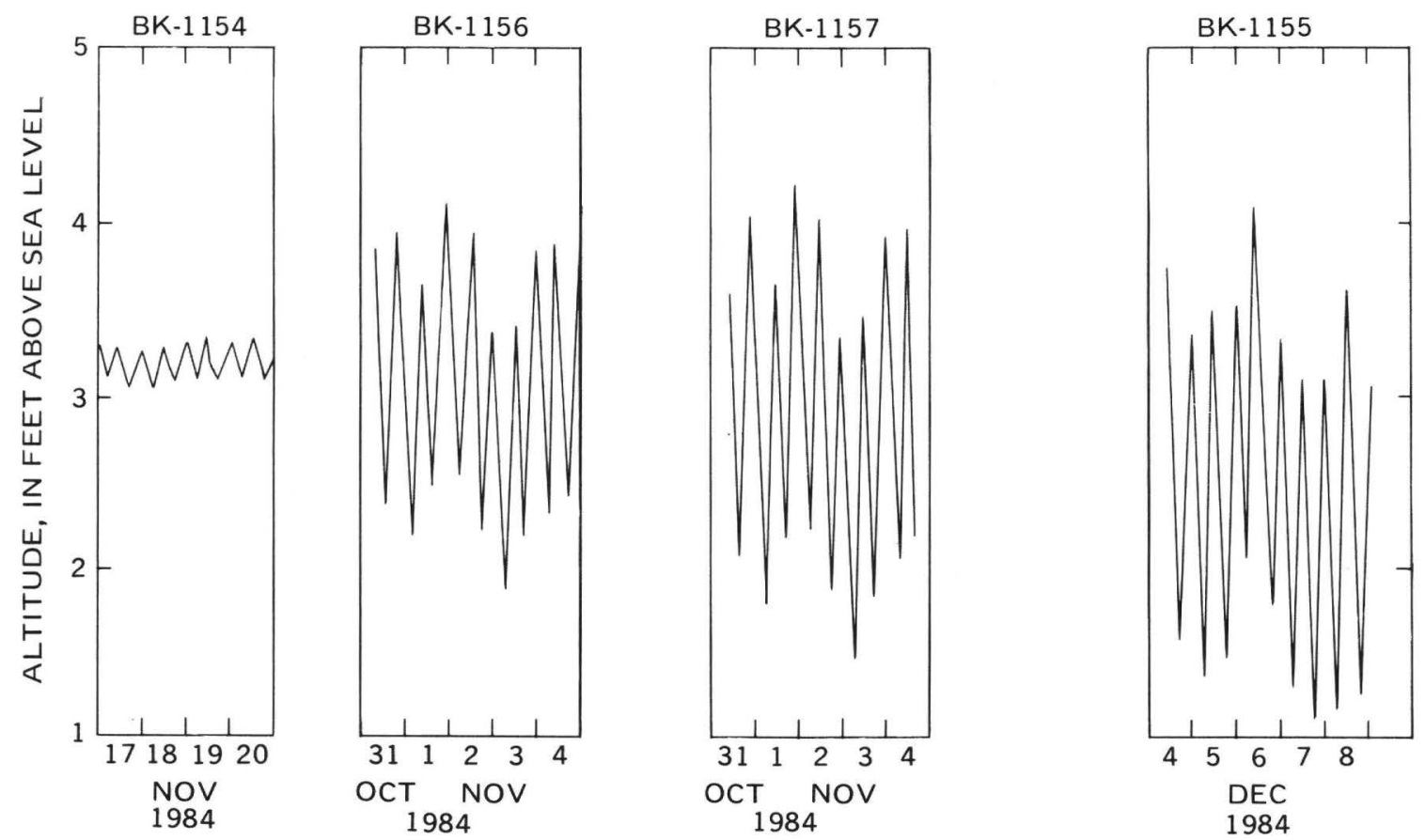

Figure 7.-Hydrographs of water levels in wells screened in the Trenton gravel (informal usage).
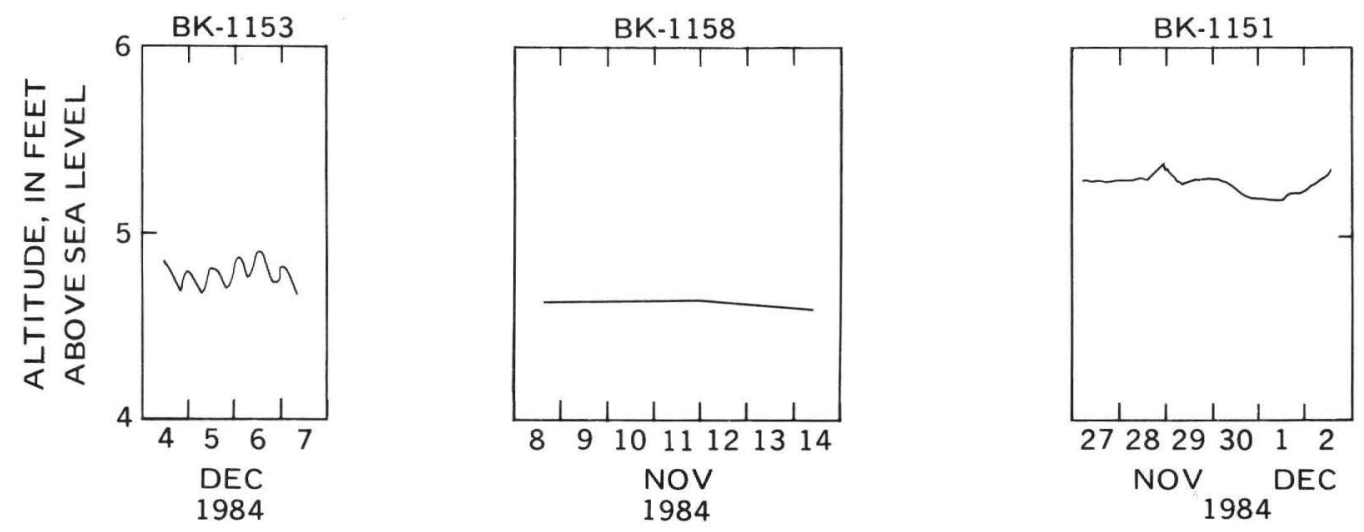

Figure 8.-Hydrographs of water levels in wells screened in the dredge spoil.

The alluvial silts and clays act as a confining layer between two waterbearing zones. Ground-water levels in the dredge spoil are higher than in the Trenton gravel (figs. 7 and 8 ), and the dredge spoil does not yield as much water or respond as well to tidal fluctuations. Ground water in the Trenton gravel is confined by the alluvium, allowing hydraulic-head variations in the river to be readily transmitted to wells. 
Flow directions in the dredge spoil are unpredictable. Water levels tend to change quickly, because the ground water is recharged rapidly by precipitation, and the dredge spoil has little storage. Variations in the altitude and thickness of the alluvial silts and clays that underlie the dredge spoil probably affect water levels. Water-level and land-surface altitudes of the dredge spoil decrease toward the river, but there are too few data points and too much variability in the dredge spoil to construct a watertable map.

Ground-water flow directions in the Trenton gravel reverse during each tidal cycle. Water-table maps are shown at low, mean, and high tide in figures 9-11. At low tide, flow is toward the Delaware River and Neshaminy Creek, but the river and creek recharge the aquifer as the tide rises.

Ultimately, ground water beneath the soil-factory site discharges to the Delaware River or to Neshaminy Creek. Ground water in the deepest Coastal Plain sediments in South Philadelphia commonly flows beneath the Delaware River toward New Jersey, but, at Neshaminy State Park, the river channel is dredged to bedrock, preventing the flow of ground water underneath the river. 


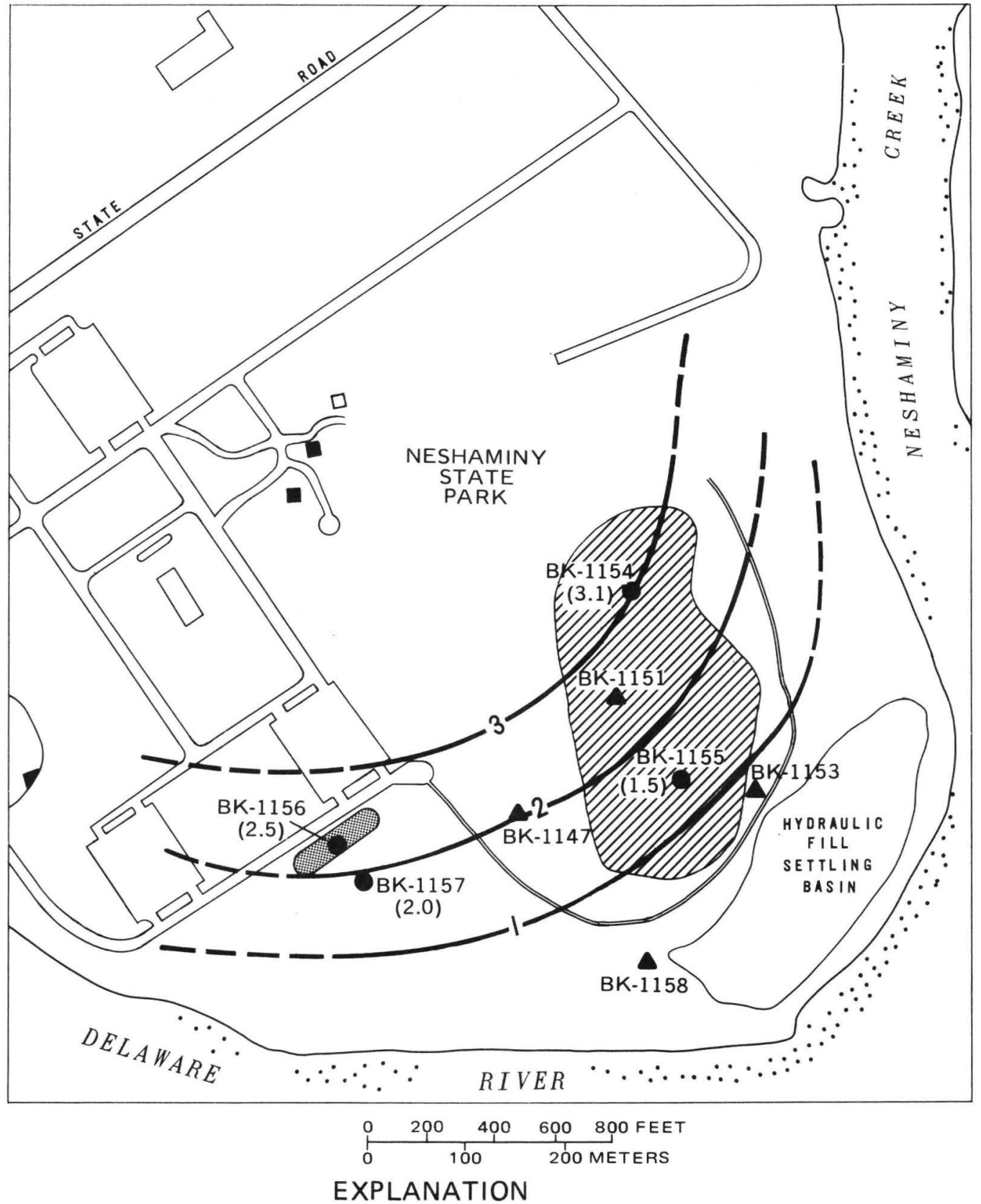

$\therefore \therefore$ TIDAL FLATS

APPROXIMATE AREA OF SOIL-FACTORY SITE

APPROXIMATE AREA OF SOIL-EMPLACEMENT SITE

- - 3- POTENTIOMETRIC-SURFACE CONTOUR-Shows altitude at which water level would have stood in tightly cased wells. Dashed where approximately located. Contour interval is 1 foot. Datum is sea level

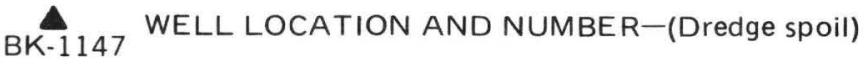

BK-1157 WELL LOCATION AND NUMBER (Trenton gravel of informal usage)

(2.0) WATER LEVEL

Figure 9.--Potentiometric surface of the Trenton gravel at low tide, November-December 1984. 


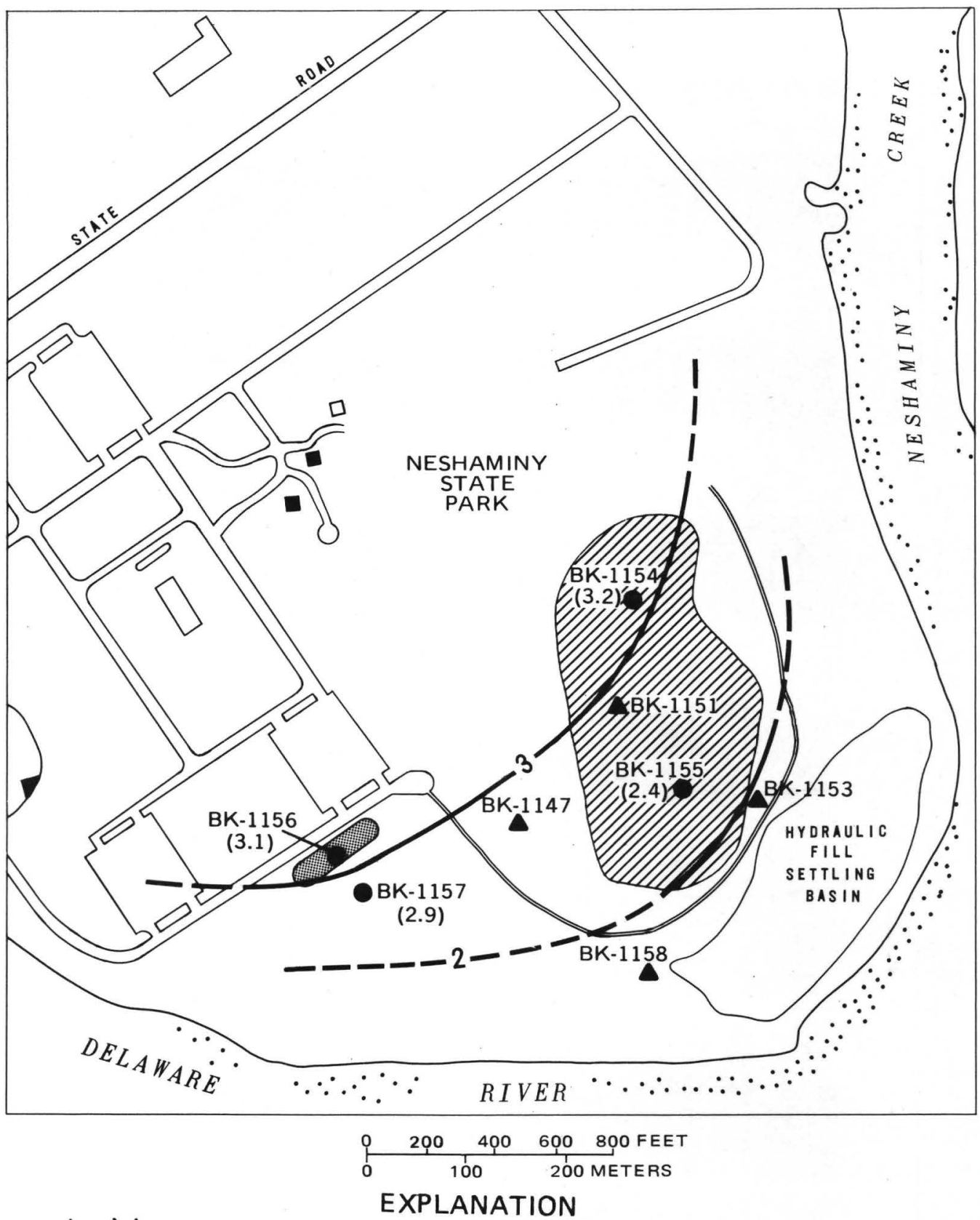

$\therefore \therefore \therefore$ TIDAL FLATS

APPROXIMATE AREA OF SOIL-FACTORY SITE

APPROXIMATE AREA OF SOIL-EMPLACEMENT SITE

- -3- POTENTIOMETRIC-SURFACE CONTOUR-Shows altitude at which water level would have stood in tightly cased wells. Dashed where approximately located. Contour interval is 1 foot. Datum is sea level

BK-1147 WELL LOCATION AND NUMBER-(Dredge spoil)

BK-1157 WELL LOCATION AND NUMBER (Trenton gravel of informal usage)

(2.0) WATER LEVEL

Figure 10.--Potentiometric surface of the Trenton gravel at mean tide, November-December 1984. 


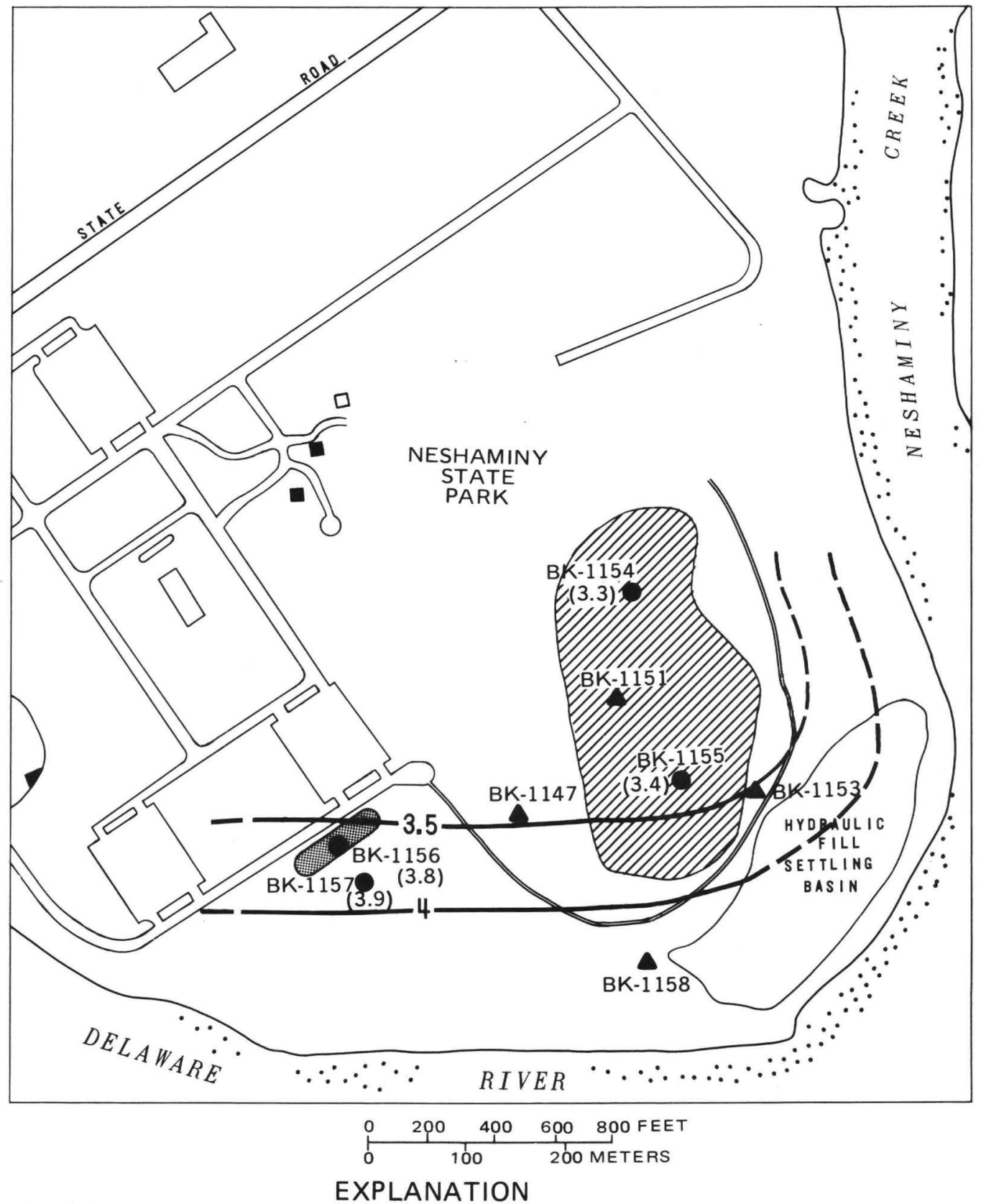

$\therefore \therefore \therefore$ TIDAL FLATS

APPROXIMATE AREA OF SOIL-FACTORY SITE

APPROXIMATE AREA OF SOIL-EMPLACEMENT SITE

POTENTIOMETRIC-SURFACE CONTOUR-Shows altitude at which water level would have stood in tightly cased wells. Dashed where approximately located. Contour interval is $1 / 2$ foot. Datum is sea level.

BK-1 147 WELL LOCATION AND NUMBER-(Dredge spoil)

BK-1157 WELL LOCATION AND NUMBER (Trenton gravel of informal usage)

(2.0) WATER LEVEL

Figure 11.--Potentiometric surface of the Trenton gravel at high tide, November-December 1984. 


\section{Monitoring Program}

Six ground-water monitoring wells were drilled in 1981 at locations approved by the Pennsylvania Department of Natural Resources. The six well locations are identified as existing we11s in figure 2. In 1983, five additional monitoring wells were drilled under specifications and at locations determined by the U.S. Geological Survey. These well locations are identified as new wells in figure 2. Well-construction data, including drilling method, depth, screened interval, and land-surface elevation are given in table 4. Both sets of wells were constructed with PVC casing, and the annulus backfilled with either drill cuttings or gravel. The surface around all wells was sealed with a cement collar, and steel protective caps were installed.

Table 4.--Summary of well-construction data

\begin{tabular}{|c|c|c|c|c|c|c|}
\hline $\begin{array}{l}\text { Local } \\
\text { We11 } \\
\text { Number }\end{array}$ & $\begin{array}{l}\text { Drilling } \\
\text { method }\end{array}$ & $\begin{array}{l}\text { Hole } \\
\text { depth } \\
\text { (feet) }\end{array}$ & $\begin{array}{c}\text { Casing } \\
\text { Diameter } \\
\text { (inches) }\end{array}$ & $\begin{array}{l}\text { Screened } \\
\text { interval } \\
\text { (below land } \\
\text { surface) } \\
\text { (feet) }\end{array}$ & $\begin{array}{l}\text { Unit present } \\
\text { in screened } \\
\text { interval }\end{array}$ & $\begin{array}{c}\text { Altitude of } \\
\text { land surface, } \\
\text { above sea level } \\
\text { (feet) }\end{array}$ \\
\hline $\mathrm{BK}-1147$ & Hollow auger & 49 & 2 & $0-11.5$ & Dredge spoil & 11.76 \\
\hline $\mathrm{BK}-1148$ & Hollow auger & 30 & 2 & $9.7-27.7$ & Trenton gravel & 16.11 \\
\hline BK -1149 & Hollow auger & 30 & 2 & $7.6-19.6$ & $\begin{array}{l}\text { Dredge spoil, } \\
\text { Trenton gravel }\end{array}$ & 18.77 \\
\hline $\mathrm{BK}-1150$ & Hollow auger & 25 & 2 & $7.5-22.5$ & Dredge spoil & 18.58 \\
\hline $\mathrm{BK}-1151$ & Mud rotary & 27 & 6 & $15-25$ & $\begin{array}{l}\text { Dredge spoil, } \\
\text { Trenton gravel }\end{array}$ & 24.23 \\
\hline BK -1153 & Mud rotary & 25 & 6 & $15-25$ & $\begin{array}{l}\text { Dredge spoil, } \\
\text { Trenton gravel }\end{array}$ & 20.26 \\
\hline BK-1154 & Mud rotary & 37 & 6 & $20-30$ & Trenton gravel & 23.75 \\
\hline $\mathrm{BK}-1155$ & Mud rotary & 37 & 6 & $25-35$ & Do & 23.53 \\
\hline $\mathrm{BK}-1156$ & Mud rotary & 44 & 6 & $30-40$ & Do & 20.02 \\
\hline BK-1157 & Mud rotary & 35 & 6 & $20-30$ & Dó & 11.45 \\
\hline BK -1158 & Mud rotary & 30 & 6 & $17-27$ & Dredge spoil & 20.13 \\
\hline
\end{tabular}

Water-quality sampling began in 1981 after the initial application of composted sewage sludge on a 4.2-acre test plot within the present soil-factory area. The sampling and analysis was performed by the City of Philadelphia periodically until October 1983, when the soil-factory area was expanded to a 10-acre plot. Analyses for pH, dissolved solids, alkalinity, nutrients, and heavy metals were performed.

In October 1983, prior to expanding the sludge-disposal site to the current (1985) 10 acres, background water-quality samples were collected at wel1s $\mathrm{BK}-1154, \mathrm{BK}-1155, \mathrm{BK}-1156, \mathrm{BK}-1157$, and $\mathrm{BK}-1158$. The remaining wells were not sampled because they either could not be pumped with a 4-inch submers- 
ible pump, were destroyed, or, in the case of well BK-1151, could not be pumped without drawing the water level below the pump intake. Field determinations of $\mathrm{pH}$, alkalinity, and specific conductance were performed and samples collected for laboratory analysis after a volume equal to three times the volume of water stored in the well bore had been pumped. Analyses for volatile organic compounds, trace metals, nutrients, and some common dissolved constituents were performed at the U.S. Geological Survey laboratory in Atlanta, Georgia, by the methods described by Skougstad and others (1979) and by Wershaw and others (1983). Analysis of volatile organic compounds was discontinued after the initial sampling because they were not detected. If they were present in the sludge, the high temperatures attained during the composting process may have decomposed them or driven them off.

\section{Chemical and Physical Characteristics}

Water-quality data for wells BK-1147, BK-1148, and BK-1153, December 1981 through January 1983, are listed in table 5. Collection and analysis of water samples by the City of Philadelphia started when the 4.2-acre test plot was constructed. Because the samples were bailed and were not filtered, these results, especially for metals, cannot be compared directly with later U.S. Geological Survey analyses. Comparison with maximum contaminant levels in U.S. Environmenta1 Protection Agency (USEPA) water-quality regulations is also of little value, because the samples probably contained substantially more suspended sediment than would be present in drinking water. Beginning in October 1983, water samples from the wells were collected and analyzed by the U.S. Geological Survey, and soon afterward the soil factory was expanded to 10 acres. Monthly sampling continued through March 1985. The analytical results for major ions and trace elements are listed in the appendix. The analysis of volatile organic compounds are given in table 6 .

Ground-water chemistry at Neshaminy State Park is of two distinct types as depicted in plots of $\mathrm{pH}$, specific conductance, and dissolved organic carbon for each of the six wells monitored by the U.S. Geological Survey (figs. 12-14). Water from wells BK-1153, BK-1155, and BK-1158 consistent1y has higher $\mathrm{pH}$ and specific conductance, and concentrations of dissolved organic carbon than we11s $B K-1154, B K-1156$, and $B K-1157$ except that the quality of the water from well BK-1155 more resembled that of water from the latter we11s in October 1983.

The different chemical character of water types between monitoring wells is also indicated by the concentrations of dissolved sulfate, iron, ammonium (figs. 15-17), calcium, cadmium, nickel, and alkalinity listed in the appendix.

Hydrogeologic factors determine the type of ground water encountered at the park. The presence of two chemical types of water is related to the presence of two water-bearing zones. Water characterized by low $\mathrm{pH}$ and low specific conductance is present in wells screened in the Trenton gravel; these wells are significantly affected by tidal fluctuations. Water with higher $\mathrm{pH}$ and specific conductance is present in wells screened in dredge spoil; these wells are not significantly affected by tidal fluctuations. 
Well BK-1155 is an exception because the source of water in this well apparently changed from the Trenton gravel type to the dredge spoil type after the October 1983 sampling. This well is screened in the Trenton gravel, but leakage of ground water through the Holocene alluvium may be occurring, either because the annulus was not effectively sealed during construction or the alluvium is absent near the wel1. We11 BK-1151, which is 300 feet updip from BK-1155, penetrated the contact between the dredge spoil and the Trenton gravel, but did not encounter any Holocene alluvium.

Table 5.--Selected chemical analyses of ground water by the City of Philadelphia [Concentrations in milligrams per liter; a dash indicates no data]

\begin{tabular}{|c|c|c|c|c|c|c|c|c|c|}
\hline $\begin{array}{c}\text { Local } \\
\text { we11 } \\
\text { number }\end{array}$ & Date & $\underset{\text { (units) }}{\mathrm{pH}}$ & $\begin{array}{c}\text { Alkalinity } \\
\text { as } \mathrm{CaCO}_{3}\end{array}$ & $\begin{array}{c}\text { Total } \\
\text { dissolved } \\
\text { solids }\end{array}$ & $\begin{array}{c}\text { Ammonium } \\
\text { (as } \mathrm{N})\end{array}$ & $\begin{array}{r}\text { Nitrate } \\
(\text { as N) }\end{array}$ & $\begin{array}{r}\text { Nitrite } \\
\text { (as N) }\end{array}$ & $\begin{array}{c}\text { Phos phorus } \\
\text { (as P) }\end{array}$ & $\begin{array}{c}\text { Cadmium } \\
\text { total } \\
\end{array}$ \\
\hline \multirow[t]{5}{*}{$B K-1147$} & $12 / 30 / 81$ & 4.0 & 0.0 & 143 & 0.09 & 0.20 & 0.001 & 0.02 & 0.02 \\
\hline & $3 / 17 / 82$ & 4.4 & .0 & 112 & .04 & .68 & .001 & .02 & .01 \\
\hline & $6 / 28 / 82$ & 4.4 & .0 & 100 & .04 & .11 & .001 & .00 & .05 \\
\hline & $9 / 29 / 82$ & 4.2 & .0 & 62 & .09 & .21 & .001 & .02 & .05 \\
\hline & $1 / 19 / 83$ & 4.6 & .0 & 112 & .05 & .10 & .008 & .00 & .03 \\
\hline \multirow[t]{5}{*}{$B K-1148$} & $12 / 30 / 81$ & 6.4 & 145 & 216 & .85 & .20 & .001 & .07 & .00 \\
\hline & $3 / 17 / 82$ & 6.6 & 92 & 2,980 & .04 & 1.3 & .002 & .10 & .00 \\
\hline & $6 / 28 / 82$ & 6.5 & 105 & 172 & .07 & .49 & .003 & .00 & .05 \\
\hline & $9 / 29 / 82$ & 6.5 & 101 & 13,460 & .08 & 1.1 & .011 & 4.2 & .05 \\
\hline & $1 / 19 / 83$ & 6.8 & 115 & 152 & .04 & 1.3 & .008 & .01 & .03 \\
\hline \multirow[t]{5}{*}{$B K-1153$} & $12 / 30 / 81$ & 6.6 & 350 & 497 & 3.7 & .40 & .001 & .25 & .00 \\
\hline & $3 / 17 / 82$ & 6.5 & 228 & 282 & 1.6 & 1.1 & .002 & .10 & .01 \\
\hline & $6 / 28 / 82$ & 5.8 & 76 & 176 & .97 & .07 & .001 & .01 & .05 \\
\hline & $9 / 29 / 82$ & 6.3 & 276 & 334 & 5.4 & .16 & .005 & .12 & .05 \\
\hline & $1 / 19 / 83$ & 6.5 & 280 & 294 & 4.4 & .05 & .133 & .02 & .03 \\
\hline \multicolumn{10}{|l|}{ Loca1 } \\
\hline $\begin{array}{c}\text { we11 } \\
\text { number }\end{array}$ & Date & $\begin{array}{c}\text { Chromium } \\
\text { total }\end{array}$ & $\begin{array}{r}\text { Copper } \\
\text { total } \\
\end{array}$ & $\begin{array}{l}\text { Iron } \\
\text { total }\end{array}$ & $\begin{array}{l}\text { Lead } \\
\text { total }\end{array}$ & $\begin{array}{c}\text { Manganese } \\
\text { total }\end{array}$ & $\begin{array}{c}\text { Mercury } \\
\text { total }\end{array}$ & $\begin{array}{r}\text { Nickel } \\
\text { total } \\
\end{array}$ & $\begin{array}{l}\text { Zinc } \\
\text { total }\end{array}$ \\
\hline \multirow[t]{5}{*}{ BK-1147 } & $12 / 30 / 81$ & 0.02 & 0.10 & - & 0.00 & - & - & 0.28 & 2.3 \\
\hline & $3 / 17 / 82$ & .05 & .06 & - & .01 & - & 0.0000 & .12 & .97 \\
\hline & $6 / 28 / 82$ & .1 & .11 & - & .1 & - & - & .09 & .65 \\
\hline & $9 / 29 / 82$ & .1 & .07 & - & .1 & - & .0000 & .09 & .56 \\
\hline & $1 / 19 / 83$ & .05 & .07 & 19 & .1 & .87 & .0000 & .10 & .74 \\
\hline \multirow[t]{5}{*}{$\mathrm{BK}-1148$} & $12 / 30 / 81$ & .03 & .02 & - & .06 & - & - & .04 & .04 \\
\hline & $3 / 17 / 82$ & .05 & .00 & - & .03 & - & .0005 & .02 & .06 \\
\hline & $6 / 28 / 82$ & .1 & .02 & - & .1 & - & - & .05 & .05 \\
\hline & $9 / 29 / 82$ & .1 & .04 & - & .1 & - & .0000 & .05 & .09 \\
\hline & $1 / 19 / 83$ & .05 & .17 & 174 & .1 & 11 & .0002 & .05 & .26 \\
\hline \multirow[t]{5}{*}{ BK-1153 } & $12 / 30 / 81$ & .00 & .02 & - & .04 & - & - & .06 & .10 \\
\hline & $3 / 17 / 82$ & - & .00 & - & .02 & - & .0001 & .01 & .06 \\
\hline & $6 / 28 / 82$ & 10 & .04 & - & .2 & - & - & .05 & .14 \\
\hline & $9 / 29 / 82$ & .1 & .04 & - & .2 & - & .0007 & .05 & .13 \\
\hline & $1 / 19 / 83$ & .05 & .01 & 94 & .1 & 7.4 & .0006 & .05 & .07 \\
\hline
\end{tabular}


Table 6.--Chemical analyses of ground water for volatile organic compounds [Concentrations in micrograms per liter]

\begin{tabular}{|c|c|c|c|c|c|c|c|c|c|c|}
\hline $\begin{array}{c}\text { Local } \\
\text { we11 } \\
\text { number }\end{array}$ & $\begin{array}{c}\text { Date of } \\
\text { sample } \\
\text { October--1983 } \\
\end{array}$ & $\begin{array}{l}\text { Di- } \\
\text { chloro- } \\
\text { bromo- } \\
\text { methane } \\
\text { total } \\
\end{array}$ & $\begin{array}{l}\text { Carbon- } \\
\text { tetra- } \\
\text { chlo- } \\
\text { ride } \\
\text { total } \\
\end{array}$ & $\begin{array}{l}\text { 1,2-Di- } \\
\text { Chloro- } \\
\text { ethane } \\
\text { total }\end{array}$ & $\begin{array}{l}\text { Brom- } \\
\text { oform } \\
\text { total } \\
\end{array}$ & $\begin{array}{c}\text { Chloro- } \\
\text { D1- } \\
\text { bromo- } \\
\text { methane } \\
\text { total } \\
\end{array}$ & $\begin{array}{l}\text { Ch1oro- } \\
\text { of orm } \\
\text { total } \\
\end{array}$ & $\begin{array}{c}\text { Toluene } \\
\text { total }\end{array}$ & $\begin{array}{c}\text { Benzene } \\
\text { tota1 }\end{array}$ & $\begin{array}{l}\text { Ch1oro- } \\
\text { benzene } \\
\text { total } \\
\end{array}$ \\
\hline $\begin{array}{r}\text { BK-1154 } \\
1155 \\
1156 \\
1157 \\
1158\end{array}$ & $\begin{array}{l}13 \\
14 \\
17 \\
17 \\
17\end{array}$ & $\begin{array}{l}<1.0 \\
<1.0 \\
<1.0 \\
<1.0 \\
<1.0\end{array}$ & $\begin{array}{l}<1.0 \\
<1.0 \\
<1.0 \\
<1.0 \\
<1.0\end{array}$ & $\begin{array}{l}<1.0 \\
<1.0 \\
<1.0 \\
<1.0 \\
<1.0\end{array}$ & $\begin{array}{l}<1.0 \\
<1.0 \\
<1.0 \\
<1.0 \\
<1.0\end{array}$ & $\begin{array}{l}<1.0 \\
<1.0 \\
<1.0 \\
<1.0 \\
<1.0\end{array}$ & $\begin{array}{l}<1.0 \\
<1.0 \\
<1.0 \\
<1.0 \\
<1.0\end{array}$ & $\begin{array}{l}<1.0 \\
<1.0 \\
<1.0 \\
<1.0 \\
<1.0\end{array}$ & $\begin{array}{l}<1.0 \\
<1.0 \\
<1.0 \\
<1.0 \\
<1.0\end{array}$ & $\begin{array}{l}<1.0 \\
<1.0 \\
<1.0 \\
<1.0 \\
<1.0\end{array}$ \\
\hline $\begin{array}{c}\text { Local } \\
\text { wel1 } \\
\text { number }\end{array}$ & $\begin{array}{c}\text { Date of } \\
\text { sample } \\
\text { October--1983 }\end{array}$ & $\begin{array}{l}\text { Chloro- } \\
\text { ethane } \\
\text { total }\end{array}$ & $\begin{array}{l}\text { Ethyl- } \\
\text { benzene } \\
\text { total }\end{array}$ & $\begin{array}{l}\text { Methyl- } \\
\text { bromide } \\
\text { total }\end{array}$ & $\begin{array}{l}\text { Methyl- } \\
\text { ene } \\
\text { chlor- } \\
\text { ride } \\
\text { total } \\
\end{array}$ & $\begin{array}{l}\text { Tetra- } \\
\text { chloro- } \\
\text { ethyl- } \\
\text { ene } \\
\text { total } \\
\end{array}$ & $\begin{array}{l}\text { Tri- } \\
\text { chloro- } \\
\text { flouro- } \\
\text { methane } \\
\text { total }\end{array}$ & $\begin{array}{l}\text { 1,1-Di- } \\
\text { Chloro- } \\
\text { ethane } \\
\text { total }\end{array}$ & $\begin{array}{l}\text { 1,1-D1- } \\
\text { Chloro- } \\
\text { ethyl- } \\
\text { ene } \\
\text { total } \\
\end{array}$ & $\begin{array}{l}1,1,1- \\
\text { Tri- } \\
\text { chloro- } \\
\text { ethane } \\
\text { total }\end{array}$ \\
\hline $\begin{array}{r}\text { BK-1154 } \\
1155 \\
1156 \\
1157 \\
1158\end{array}$ & $\begin{array}{l}13 \\
14 \\
17 \\
17 \\
17\end{array}$ & $\begin{array}{l}<1.0 \\
<1.0 \\
<1.0 \\
<1.0 \\
<1.0\end{array}$ & $\begin{array}{l}<1.0 \\
<1.0 \\
<1.0 \\
<1.0 \\
<1.0\end{array}$ & $\begin{array}{l}<1.0 \\
<1.0 \\
<1.0 \\
<1.0 \\
<1.0\end{array}$ & $\begin{array}{l}<1.0 \\
<1.0 \\
<1.0 \\
<1.0 \\
<1.0\end{array}$ & $\begin{array}{l}<1.0 \\
<1.0 \\
<1.0 \\
<1.0 \\
<1.0\end{array}$ & $\begin{array}{l}<1.0 \\
<1.0 \\
<1.0 \\
<1.0 \\
<1.0\end{array}$ & $\begin{array}{l}<1.0 \\
<1.0 \\
<1.0 \\
<1.0 \\
<1.0\end{array}$ & $\begin{array}{l}<1.0 \\
<1.0 \\
<1.0 \\
<1.0 \\
<1.0\end{array}$ & $\begin{array}{l}<1.0 \\
<1.0 \\
<1.0 \\
<1.0 \\
<1.0\end{array}$ \\
\hline $\begin{array}{c}\text { Local } \\
\text { well } \\
\text { number }\end{array}$ & $\begin{array}{c}\text { Date of } \\
\text { sample } \\
\text { October--1983 }\end{array}$ & $\begin{array}{l}\text { 1,1,2- } \\
\text { Tri- } \\
\text { chloro- } \\
\text { ethane } \\
\text { tota1 } \\
\end{array}$ & $\begin{array}{l}1,1,2,2- \\
\text { Tetra- } \\
\text { chloro- } \\
\text { ethane } \\
\text { toial } \\
\end{array}$ & $\begin{array}{l}\text { 1,2-D1- } \\
\text { chloro- } \\
\text { propane } \\
\text { total }\end{array}$ & $\begin{array}{l}\text { Chloro- } \\
\text { ethyl- } \\
\text { ene } \\
\text { total } \\
\end{array}$ & $\begin{array}{l}1,3-D 1 \\
\text { chloro- } \\
\text { propane } \\
\text { total }\end{array}$ & $\begin{array}{l}\quad 2- \\
\text { Chloro- } \\
\text { ethyl- } \\
\text { vinyl- } \\
\text { ether } \\
\text { total } \\
\end{array}$ & $\begin{array}{c}\text { Di- } \\
\text { Chloro- } \\
\text { Di- } \\
\text { fluoro- } \\
\text { methane } \\
\text { total }\end{array}$ & $\begin{array}{l}\text { Vinyl } \\
\text { chlo- } \\
\text { ride } \\
\text { total }\end{array}$ & $\begin{array}{l}\text { Tri- } \\
\text { chloro- } \\
\text { ethyl } \\
\text { ene } \\
\text { total } \\
\end{array}$ \\
\hline $\begin{array}{r}\text { BK-1154 } \\
1155 \\
1156 \\
1157 \\
1158\end{array}$ & $\begin{array}{l}13 \\
14 \\
17 \\
17 \\
17\end{array}$ & $\begin{array}{l}<1.0 \\
<1.0 \\
<1.0 \\
<1.0 \\
<1.0\end{array}$ & $\begin{array}{l}<1.0 \\
<1.0 \\
<1.0 \\
<1.0 \\
<1.0\end{array}$ & $\begin{array}{l}<1.0 \\
<1.0 \\
<1.0 \\
<1.0 \\
<1.0\end{array}$ & $\begin{array}{l}<1.0 \\
<1.0 \\
<1.0 \\
<1.0 \\
<1.0\end{array}$ & $\begin{array}{l}<1.0 \\
<1.0 \\
<1.0 \\
<1.0 \\
<1.0\end{array}$ & $\begin{array}{l}<1.0 \\
<1.0 \\
<1.0 \\
<1.0 \\
<1.0\end{array}$ & $\begin{array}{l}<1.0 \\
<1.0 \\
<1.0 \\
<1.0 \\
<1.0\end{array}$ & $\begin{array}{l}<1.0 \\
<1.0 \\
<1.0 \\
<1.0 \\
<1.0\end{array}$ & $\begin{array}{l}<1.0 \\
<1.0 \\
<1.0 \\
<1.0 \\
<1.0\end{array}$ \\
\hline
\end{tabular}



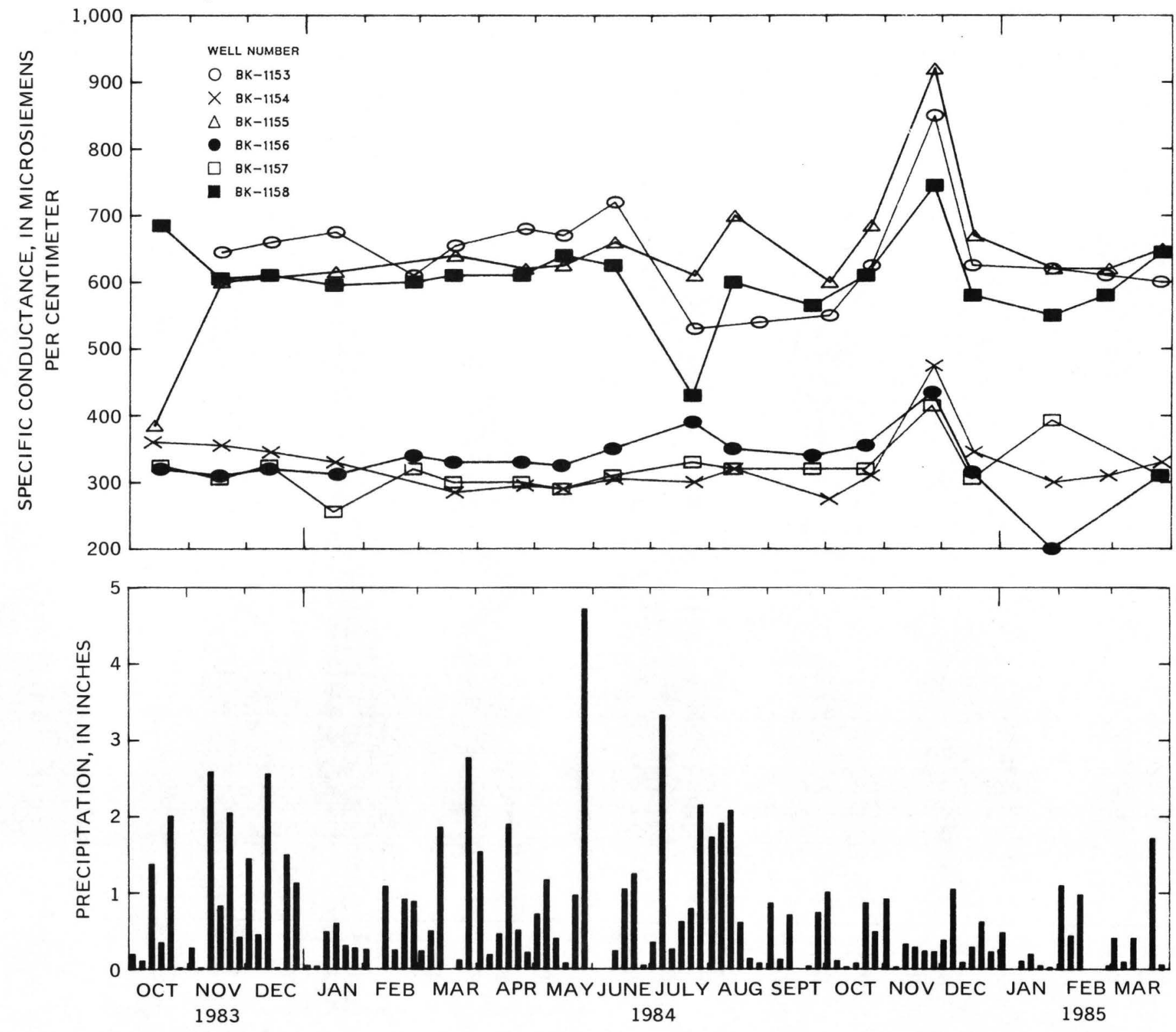

Figure 12.-Specific conductance of ground water and precipitation in 5-day increments, October 1983 to March 1985. 


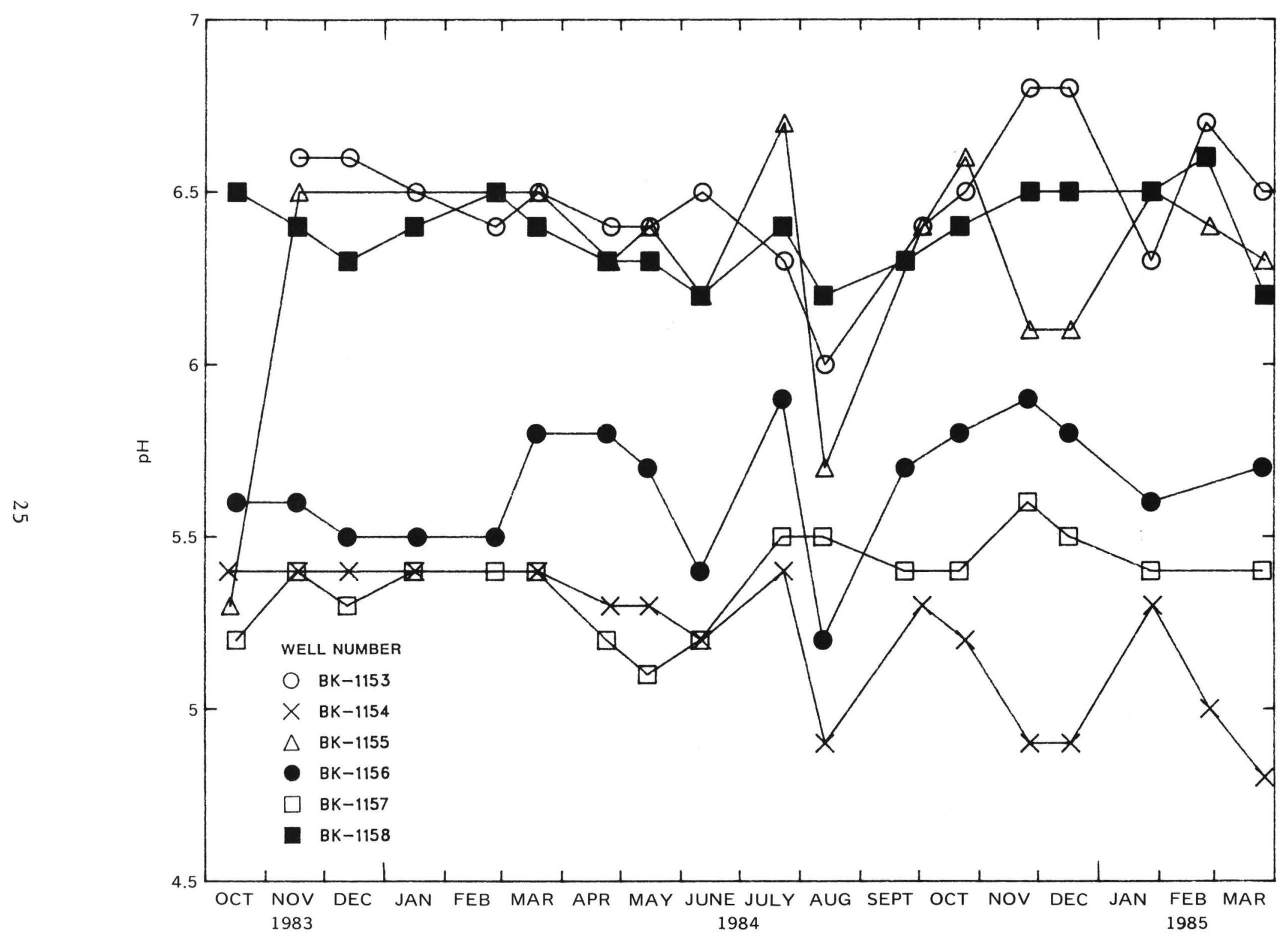

Figure 13. -pH of ground water, October 1983 to March 1985. 


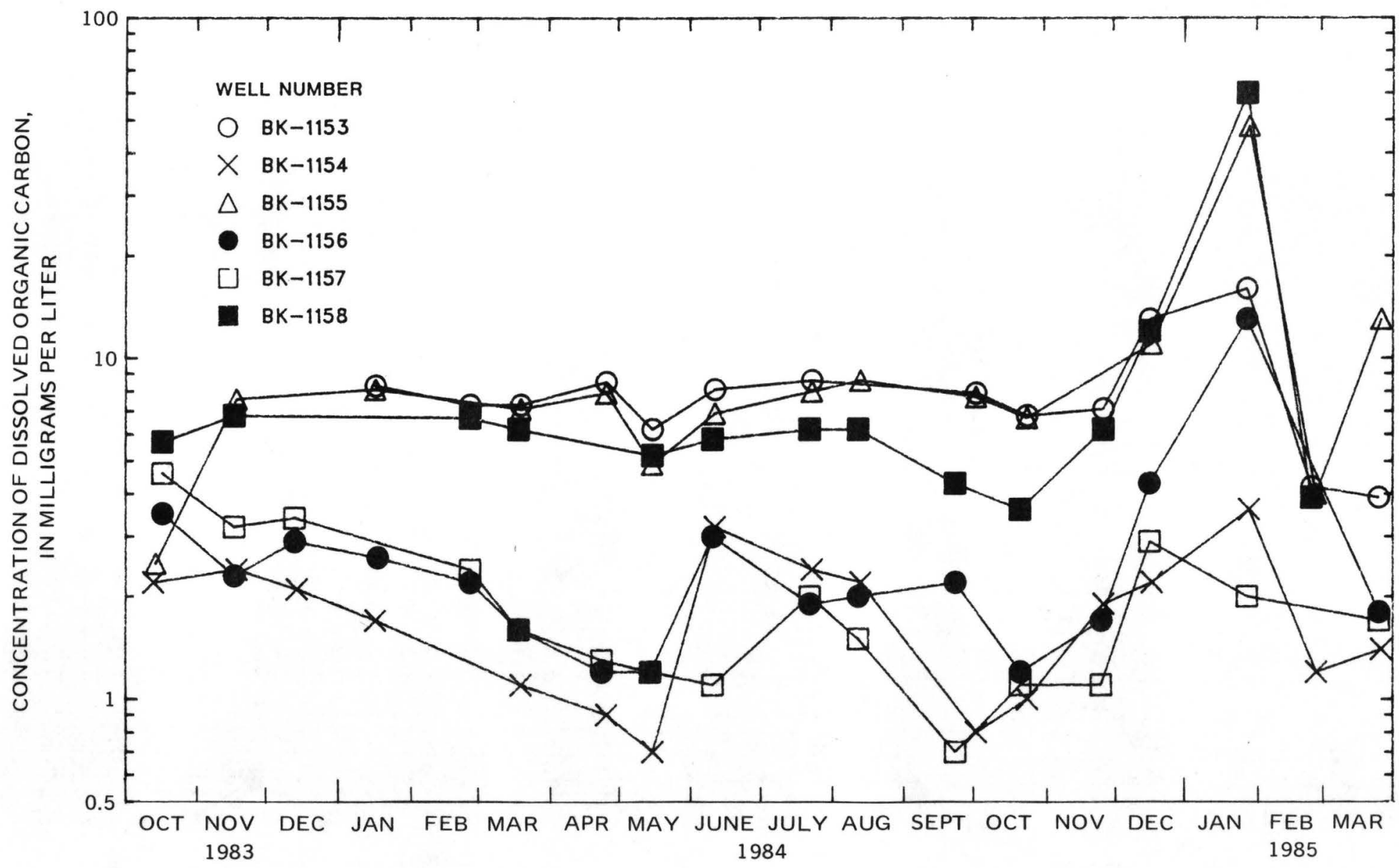

Figure 14.-Dissolved organic carbon in ground water, October 1983 to March 1985. 


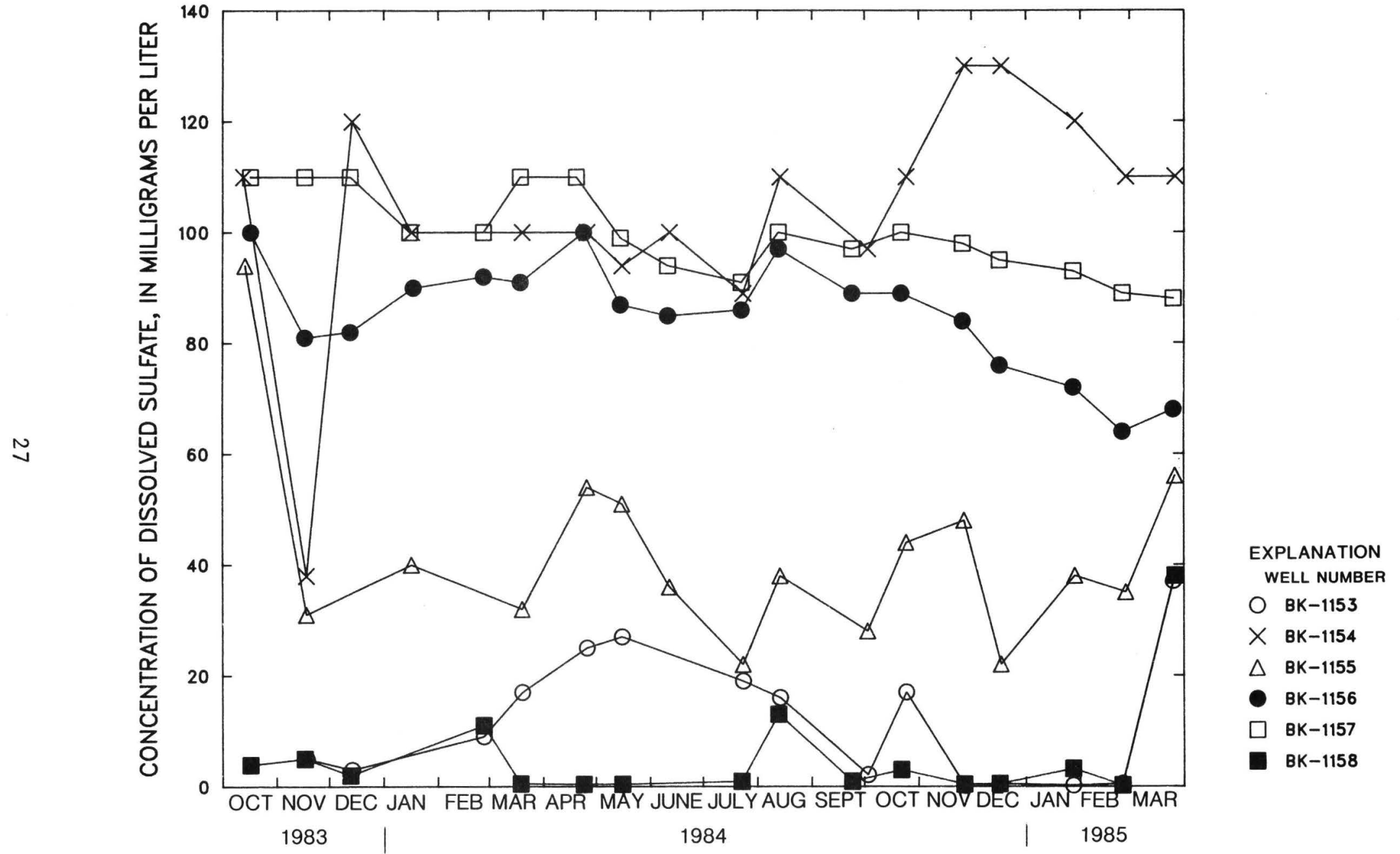

Figure 15.--Dissolved sulfate in ground water, October 1983 to March 1985. 


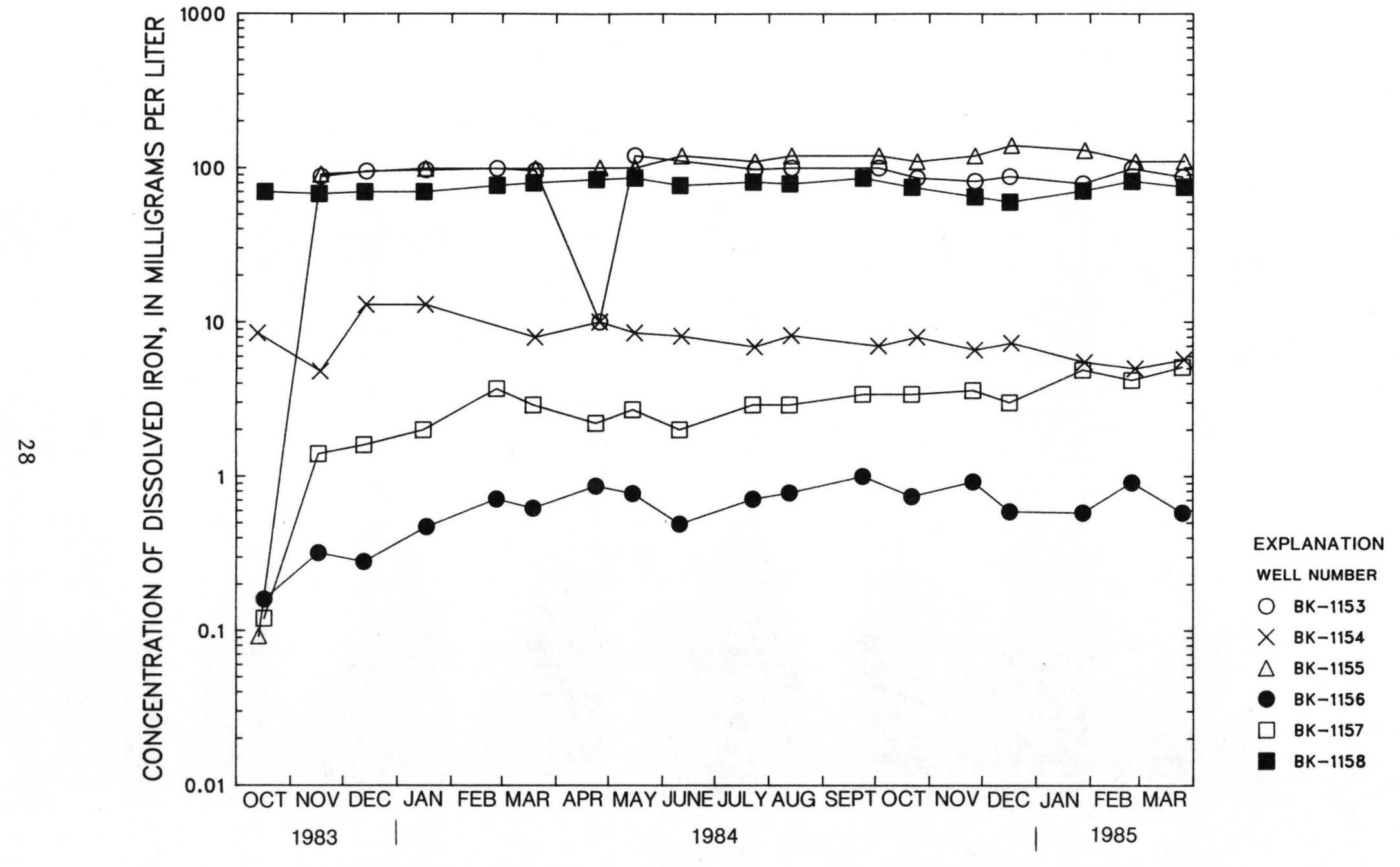

Figure 16.--Dissolved iron in ground water, October 1983 to March 1985. 


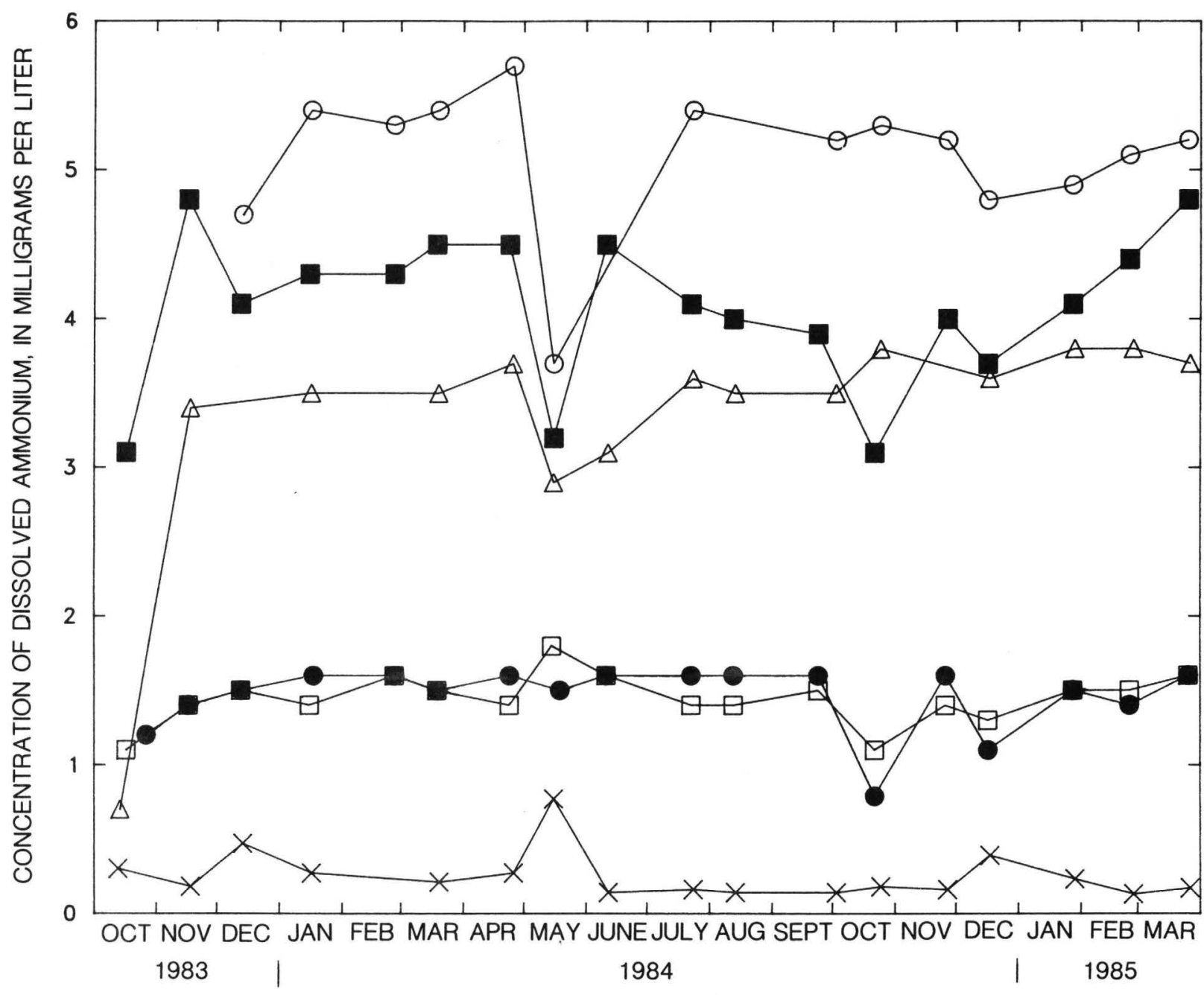

EXPLANATION WELL NUMBER

O $B K-1153$

$\times$ BK-1154

$\triangle \mathrm{BK}-1155$

BK-1156

$\square$ BK-1157

- BK-1158

Figure 17.--Dissolved ammonium in ground water, October 1983 to March 1985 
Identification of water-quality changes at the soil factory must take into consideration the source of water that is being analyzed. Under natural conditions, ground water in the dredge spoil is more mineralized than ground water in the Trenton gravel, so water in two of the downgradient wells, $B K-1153$ and BK-1158, should contain more dissolved substances than wells screened in the Trenton gravel. Similarly, because we 11 BK-1155 yields water that originates in the dredge spoil, it should yield water containing more dissolved substances than water from well BK-1154 even though both penetrate the sludge-disposal area. Furthermore, upgradient and downgradient flow directions are not easily predicted in tidally influenced aquifers.

During the 18 months of ground-water monitoring by the U.S. Geological Survey, significant changes in the concentration of nutrients above background levels did not occur except for a temporary increase in organic niirogen. From April through June 1984, water from most we 11 s showed an increase in organic nitrogen ( $\mathrm{fig} \cdot 18$ ). The increase was most evident in wells BK-1153 and BK-1158 screened in (or partly in) dredge spoil. An increase also occurred in wells $\mathrm{BK}-1155$ and $\mathrm{BK}-1156$, both screened in the Trenton gravel where the Holocene alluvium is absent at or near the well. The increase may have been related to ground-water recharge from the 18 inches of rain that fell in March, April, and May.

Heavy-metal concentrations did not change much during the study period. Concentrations of cadmium were near or at the maximum contaminant level in the USEPA (1977) primary drinking-water regulations in water from wells screened in dredge spoil. However, the only significant change in cadmium concentration occurred in wel1 BK-1155 from October to November 1983, when the water-quality type changed. Elevated dissolved-iron and manganese concentrations are common throughout the Pennsylvania Coastal Plain. Concentrations of dissolved constituents at Neshaminy State Park, as in other areas, far exceed maximum contaminant levels in the USEPA secondary drinking water regulations of $0.3 \mathrm{mg} / \mathrm{L}$ for iron and $0.05 \mathrm{mg} / \mathrm{L}$ for manganese. Although the dissolved-iron concentrations in the Trenton gravel commonly differ from those in the dredge spoil (fig. 16), the dissolved-manganese concentrations are typically 6 to $15 \mathrm{mg} / \mathrm{L}$ for water from all wells except BK-1154, where the concentrations are generally 1 to $2 \mathrm{mg} / \mathrm{L}$ (fig. 19).

Specific conductance and $\mathrm{pH}$ of ground water also were unaffected by the sludge. In November 1984, specific conductance did show a temporary increase in water from all wells, but this increase does not appear to be related to any activity at the soil factory.

From October 1983 to March 1985, sulfate concentrations ranged from less than $0.5 \mathrm{mg} / \mathrm{L}$ to more than $30 \mathrm{mg} / \mathrm{L}$ in water from 2 we $11 \mathrm{~s}--\mathrm{BK}-1153$ and BK-1158--that are screened in the dredge spoil. The changes appear to be nearly random, but may be caused by oxidation-reduction reactions. Similar changes were not observed for iron, manganese, and nitrogen. Hem, (1985, p. 116) noted sulfate reduction in water from wells elsewhere in the Atlantic Coasta1 P1ain. 
A strong reducing environment in the dredge spoil is indicated because most of the nitrogen is present as ammonium and concentrations of iron and manganese are elevated. Water from the Trenton gravel has much higher concentrations of sulfate than that from the dredge spoil. This may be caused by an environment that is at least slightly less reduced than that in the dredge spoil.

The addition of lime appears to be successful in preventing a $\mathrm{pH}$ reduction and may explain the higher $\mathrm{pH}$ of ground water from the dredge spoil compared to ground water from the Trenton gravel. The stability of specific conductance indicates that appreciable amounts of soluble alkaline or alkaline-earth compounds have not leached into the ground-water system despite the apparent impact of the addition of lime on $\mathrm{pH}$.

Thus, application of sewage sludge has not produced significant adverse effects on ground-water quality as of March 1985. The absence of significant chemical change with time implies either that little of the more than 100 inches of precipitation that fell from April 1983 to March 1985 reached the water table, or, more likely, that a mechanism exists beneath the soil factory site, perhaps related to the clay layers present in the dredge spoil (figs. 5 and 6 ), that retards or prevents the downward migration of contaminants. This study was not of sufficient duration to prove that the ground water will not be adversely affected in the future as a result of repeated sludge applications to the same site. 


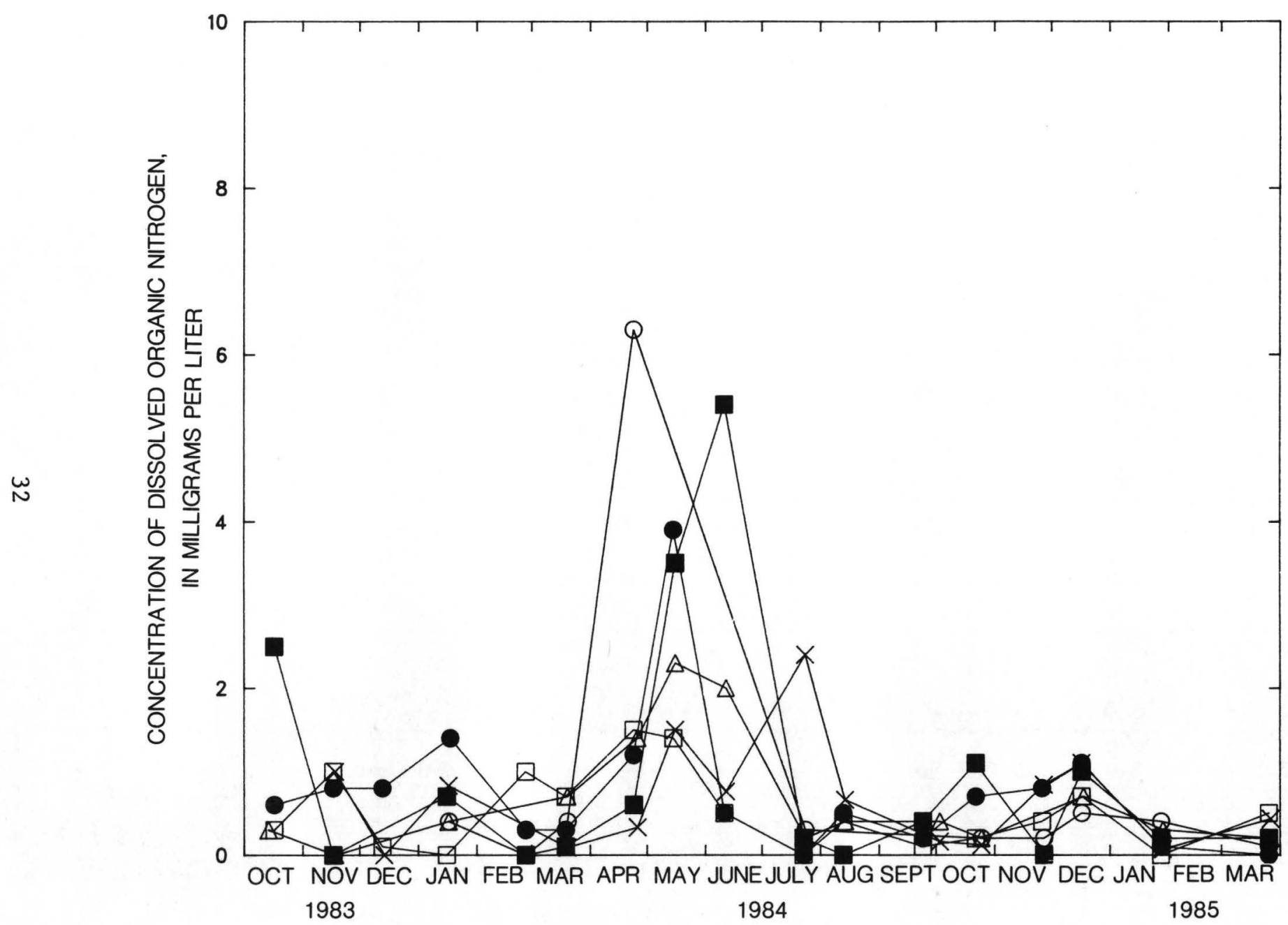

EXPLANATION WELL NUMBER

O $B K-1153$

$\times \quad B K-1154$

$\triangle B K-1155$

- BK-1156

$\square$ BK-1157

D BK-1158

Figure 18.--Dissolved organic nitrogen in ground water, October 1983 to March 1985. 


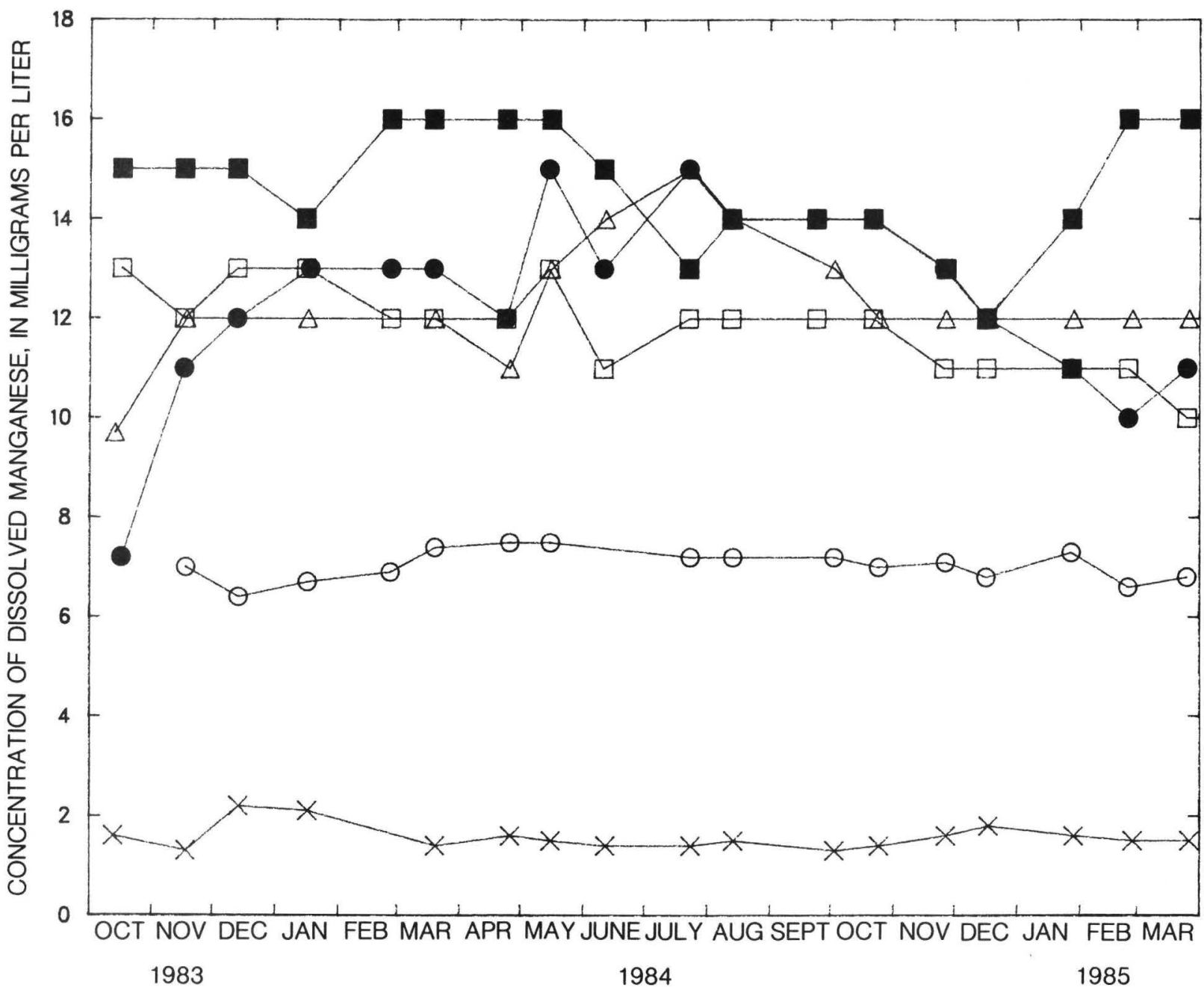

EXPLANATION WELL NUMBER

O BK -1153

$\times \quad B K-1154$

$\triangle B K-1155$

- $B K-1156$

D BK-1157

BK -1158

Figure 19.--Dissolved manganese in ground water, October 1983 to March 1985. 
Composted sewage sludge from the City of Philadelphia was mixed with infertile dredge spoil at Neshaminy State Park to produce a soil capable of sustaining vegetative growth. Six wells were installed in the Holocene deposits and underlying informally named "Trenton gravel" of pleistocene age to monitor contaminant releases. Monthly ground-water samples were collected by the U.S. Geological Survey for 18 months and analyzed for pH, specific conductance, nutrients, common dissolved solids, and heavy metals.

Two ground-water types were present; one in the Trenton gravel and the other in the dredge spoil. The only significant changes in ground-water chemistry was a temporary increase in organic nitrogen 6 months after sludge was deposited on a 10-acre plot. A confining layer of alluvial silty clay retarded the downward movement of organic nitrogen into the Trenton gravel, except where the alluvium is absent. Significant changes in concentrations of heavy metals, nitrate, ammonium, and in specific conductance did not occur in either water-bearing zone. Cadmium concentrations were near or at the maximum contaminant level in the USEPA primary drinking-water regulations in the wells screened in Holocene deposits, but did not show much change over time. Although application of sewage sludge did not significantly affect ground-water quality as of March 1985, this study was not of sufficient duration to prove that adverse effects on ground-water quality will not occur in the future with repeated sludge applications. Thus, additional monitoring and data analysis is needed before developing similar sludge-disposal projects elsewhere.

Normally, ground water discharges to the Delaware River and Neshaminy Creek. However, because the Trenton gravel is confined by the alluvium and is hydraulically connected to the Delaware River throughout its entire thickness due to channel dredging, hydraulic-head variations in the river are readily transmitted to wells. Thus, flow is toward the Delaware River and Neshaminy Creek at low tide, but the river and creek recharge the aquifer as the tide rises. Ground-water levels in the dredge spoil are higher than in the Trenton gravel and the dredge spoil does not yield as much water or respond as well to tidal fluctuations. 
Boswe11, F. C., 1975, Municipal sewage sludge and selected element applications to soil: effect on soil and fescue: Journal of Environmental Quality, v. 4, p. 267-273.

Cao, Hong-fa, Chang, A. C., and Page, A. L., 1984, Heavy metal contents of sludge-treated soils as determined by three extraction procedures: Journal of Environmental Quality, v. 13, p. 632-634.

Emmerich, W. E., Lund, L. J., Page, A. L., and Chang, A. C., 1982, Movement of heavy metals in sewage sludge-treated soils: Journal of Environmental Quality, v. 11, p. 174-178.

Greenman, D. W., 1955, Ground water resources of Bucks County, Pennyslvania: Pennsylvania Geological Survey Water Resource Report 11, 66 p.

Greenman, D. W., Rima, D. R., Lockwood, W. N., and Meisler, Harold, 1961, Ground-water resources of the Coastal Plain area of southeastern Pennsylvania: Pennsylvania Geological Survey Water Resource Report 13, $375 \mathrm{p}$.

Hem, J. D., 1985, Study and interpretation of the chemical characteristics of natural water: U.S. Geological Survey Water Supply Paper 2254, third edition, $263 \mathrm{p}$.

Higgins, A. J., 1984, Impacts on groundwater due to land application of sewage sludge: Water Resources Bulletin, v. 20, p. 425-434.

Kam, William, 1978, Effect of controlled application of sludge on groundwater quality, Ocean County, New Jersey: U.S. Geologica1 Survey Openfile Report 78-492, 87 p.

Owens, J. P., and Minard, J. P., 1979, Upper Cenozoic sediments of the Lower Delaware Valley and the Northern Demarva Peninsula, New Jersey, Pennyslvania, Delaware, and Maryland: U.S. Geological Survey Professional Paper 1067-D, 47 p.

Robson, S. G., 1976, Ground-water quality near a sewage-sludge recycling site and a landfill near Denver, Colorado: U.S. Geological Survey WaterResources Investigations 76-132, $149 \mathrm{p}$.

Sidle, R. C., and Kardos, L. T., 1977, Transport of heavy metals in a sludgetreated forested area: Journal of Environmental Quality, v. 6, p. 431-437.

Skougstad, M. W., Fishman, M. J., Friedman, L. C., Erdman, D. E., and Duncan, S. S., 1979, Methods for determination of inorganic substances in water and fluvial sediments: U.S. Geological Survey Techniques of Water-Resources Investigations, Book 5, Chap. Al, 626 p. 
Sommers, L. E., Nelson, D. W., and Silviera, D. J., 1979, Transformation of carbon, nitrogen, and metals in soils treated with waste materials: Journal of Environmental Quality, v. 8, p. 287-294.

Sylvester, M. A., 1982, Land application of wastewater and its effect on ground-water quality in the Livermore-amador Valley, Alameda County, California: U.S. Geological Survey Water-Resources Investigations Report $82-4100,53 \mathrm{p}$.

U.S. Environmental Protection Agency, 1977, National Secondary Drinking Water Regulations; Federal Register, March 31, 1977, v. 42, No. 62, part 143, p. $17,145-17,147$.

Wershaw, R. L., Fishman, M. J., Grabbe, R. R., and Lower, L. E., 1983, Methods for the determination of organic substances in water and fluvial sediments: U.S. Geological Survey Techniques of Water-Resources Investigations, Book 5, Laboratory Analysis, Chap. A3, 173 p. 

Spe- Alka- Carbon, Magne- Potas- Chlo- $\quad$ Fluo- ${ }^{-}$Nitro-

cific linity organic Calcium sium, Sodium, sium, ride, Sulfate ride, Silica, gen

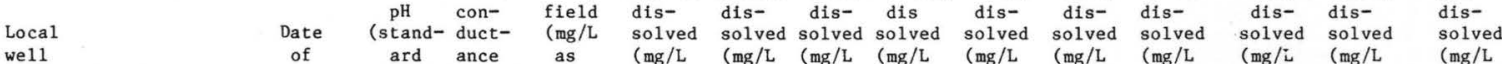

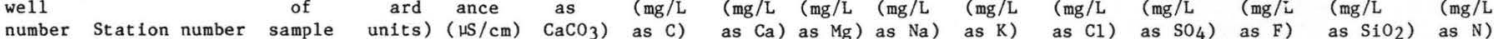

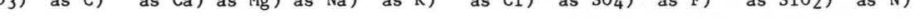

BK-1153 $40043307454430183-11-18 \quad 6.6 \quad 645$

$\begin{array}{lll}83-11-18 & 6.6 & 645 \\ 83-12-14 & 6.6 & 660 \\ 84-01-17 & 6.5 & 675 \\ 84-02-27 & 6.4 & 610 \\ 84-03-20 & 6.5 & 655 \\ & & \\ 84-04-26 & 6.4 & 680 \\ 84-05-16 & 6.4 & 670 \\ 84-06-12 & 6.5 & 720 \\ 84-07-24 & 6.3 & 530 \\ 84-08-14 & 6.0 & 540 \\ 84-10-03 & 6.4 & 550 \\ 84-10-25 & 6.5 & 625 \\ 84-11-27 & 6.8 & 850 \\ 84-12-17 & 6.8 & 625 \\ 85-01-28 & 6.3 & 620 \\ 85-02-25 & 6.7 & 610 \\ 85-03-26 & 6.5 & 600\end{array}$

BK-1154 $400440074544601 \quad 83-10-13 \quad 5.4 \quad 360$ $\begin{array}{lll}83-11-18 & 5.4 & 355 \\ 83-12-14 & 5.4 & 345\end{array}$ $\begin{array}{lll}83-12-14 & 5.4 & 345 \\ 84-01-17 & 5.4 & 330\end{array}$ 84-03-20 $5.4 \quad 285$

$84-04-26 \quad 5.3 \quad 295$ $84-05-16 \quad 5.3 \quad 290$ 84-06-12 $5.2 \quad 305$ $\begin{array}{lll}84-07-24 & 5.4 & 300 \\ 84-08-14 & 4.9 & 320\end{array}$

84-10-03 $5.3 \quad 275$ 84-10-25 $5.2 \quad 310$ $84-11-27 \quad 4.9 \quad 475$ 84-12-18 $4.9 \quad 345$ 85-01-29 5.3 300

85-02-27 $5.0 \quad 310$ 85-03-27 $4.8 \quad 330$

BK-1155 $400434074544401 \quad 83-10-14 \quad 5.3 \quad 385$ $\begin{array}{lll}83-11-18 & 6.5 & 600\end{array}$ $\begin{array}{lll}84-01-17 & -5 & 615\end{array}$ $\begin{array}{lll}84-03-20 & 6.5 & 640 \\ 84-04-26 & 6.3 & 620\end{array}$

84-05-16 $6.4 \quad 625$ $84-06-12 \quad 6.2 \quad 660$ $\begin{array}{lll}84-07-24 & 6.7 & 610\end{array}$ $84-08-14 \quad 5.7 \quad 700$ 84-10-03 $6.4 \quad 600$

$84-10-25 \quad 6.6 \quad 685$ $84-11-27 \quad 6.1 \quad 920$ $84-12-18 \quad 6.1 \quad 670$ $\begin{array}{lll}85-01-29 & 6.5 & 620 \\ 85-02-27 & 6.4 & 620\end{array}$

85-03-27 $6.3 \quad 650$

BK-1156 $400430074550001 \quad 83-10-17 \quad 5.6 \quad 320$ $\begin{array}{lll}83-10-17 & 5.6 & 320 \\ 83-11-17 & 5.6 & 310 \\ 83-12-13 & 5.5 & 320\end{array}$ $\begin{array}{lll}83-12-13 & 5.5 & 320 \\ 84-01-18 & 5.5 & 312 \\ 84-02-27 & 5.5 & 340\end{array}$

84-03-19 $5.8 \quad 330$ $\begin{array}{lll}84-04-24 & 5.8 & 330\end{array}$ $84-05-15 \quad 5.7 \quad 325$ $\begin{array}{lll}84-06-11 & 5.4 & 350\end{array}$ $\begin{array}{lll}84-06-11 & 5.4 & 350 \\ 84-23 & 5.9 & 390\end{array}$

$84-08-13 \quad 5.2 \quad 350$ $84-09-24 \quad 5.7 \quad 340$ $84-10-22 \quad 5.8 \quad 355$ $\begin{array}{lll}84-11-26 & 5.9 & 435 \\ 84-12-17 & 5.8 & 315\end{array}$

$\begin{array}{lll}85-01-28 & 5.6 & 200 \\ 85-02-25 & -- & -\end{array}$ $\begin{array}{lrr}85-02-25 & -\overline{7} & - \\ 85-03-26 & 5.7 & 310\end{array}$

\section{0}

392
390

390
390

390
418

--

--.3
7.3
7.3

$\begin{array}{ll}-- & - \\ 53 & 14 \\ 56 & 15 \\ 56 & 15\end{array}$

--
14
15
16

$8.5 \quad 57 \quad 16$

380
416

$\begin{array}{lll}8.5 & 57 & 16 \\ 6.2 & 57 & 16\end{array}$

8.1
8.6
--

7.9

7.9
6.8

6.8
7.1
13

13
16

3.

182.

$\begin{array}{lll}2.2 & 19 & 1 \\ 2.4 & - & - \\ 2.1 & 20 & 1 \\ 1.7 & 19 & 14\end{array}$

1.7
1.1

$\begin{array}{lll}.90 & 16 & 12 \\ .70 & 15 & 12 \\ 3.2 & 16 & 12 \\ 2.4 & 15 & 12\end{array}$

2. 2

16 a / 1.

12 / 1.9

13 a 16 . 2.

$\begin{array}{ll}10 & 1 \\ 14 & 1.4\end{array}$

$56 \quad 2.5$

322

370
326

7.6
8.1

7.1

$\begin{array}{ll}348 & 4.9 \\ 386 & 6.9 \\ 394 & 8.0\end{array}$

368
360

$408 \quad 6.7$

$\begin{array}{ll}318 \\ 360 \\ 320 \text { a/ } & 11\end{array}$

320 a / 48

302

$\begin{array}{llll}40 & 3.5 & 33 & 13 \\ 52 & 2.3 & -- & -- \\ 54 & 2.9 & 27 & 13 \\ 52 & 2.6 & 29 & 14\end{array}$

$\begin{array}{lll}1.6 & 28 & 14 \\ 1.2 & 29 & 14\end{array}$

1.2

$3.0 \quad--\quad-$

$2.0 \quad 29 \quad 14$

1.2

1.7

4. 3

13

$1 . \overline{8}$

-- $\quad--$

$\begin{array}{lr}14 & 8.3 \\ -- & -- \\ -- & --\end{array}$

$--$

--

-- -

-- $=$

$--$

--

$\begin{array}{ll}-- & - \\ -- & --\end{array}$

$-$

$-\overline{-}$

$=$

$\equiv 三$ $\begin{array}{lllrl}-- & -- & -- & <5.0 & - \\ -- & - & - & 3.0 & - \\ -- & -- & - & - & - \\ -- & -- & - & 9.0 & - \\ -- & -- & - & 17 & -\end{array}$

$\begin{array}{ll}-- & - \\ -- & --\end{array}$

$\begin{array}{lllllll}-- & -- & -- & 27 & - & - & - \\ -- & -- & - & 24 & - & - & - \\ - & - & 19 & - & -\end{array}$

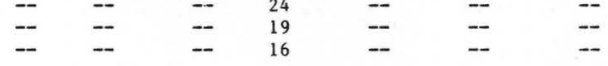

$\begin{array}{lll}-- & - & - \\ -- & - & -\end{array}$

$\begin{array}{lll}-- & - & - \\ -- & -- & - \\ -- & -- & -\end{array}$

$\begin{array}{cc}2.1 & -- \\ 17 & --\end{array}$

$\begin{array}{rr}.2 & -- \\ .5 & --\end{array}$

$-$

148.3

$-$

$37^{.5} \quad--$

$\begin{array}{ccccc} & 110 & <0.10 & 11 & 1.8 \\ -- & 38 & -- & -- & 2.0 \\ -- & 120 & -- & - & .97 \\ - & 100 \mathrm{a} / & - & - & 2.5 \\ - & 100 \text { a } / & -- & -- & 1.2\end{array}$

$\begin{array}{rrrrrrr}-- & - & - & 100 & - & - & 1.6 \\ - & -- & - & 94 & -- & - & 3.3\end{array}$

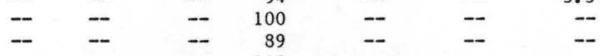

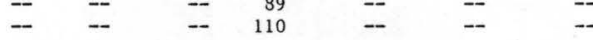

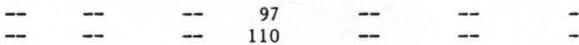

$=\quad--\quad=\quad 130$

$\overline{-}-\overline{-} \quad \overline{-} \quad \overline{-} \quad 130$

$=\quad--\quad=\quad 110$

$\begin{array}{llll}7.4 & 2.4 & 7.2 & 94\end{array}$

$\begin{array}{lllll}7.4 & 2.4 & -2 & 94 & <.: 0 \\ -- & -- & - & 31 & -- \\ -- & -- & -- & 40 \mathrm{a} / & -- \\ -- & - & -- & 32 & --\end{array}$

32
54

$\overline{--}$

-

$\begin{array}{lll}-- & -- & -- \\ -- & -- & -\end{array}$

$\begin{array}{lll}- & - & - \\ -- & - & -\end{array}$

$13 \quad 3.0 \quad 16$ 


\begin{tabular}{|c|c|c|c|c|c|c|c|c|c|c|c|c|c|c|c|c|}
\hline $\begin{array}{l}\text { Nitro- } \\
\text { gen, } \\
\text { ammonia } \\
\text { dis- } \\
\text { solved } \\
\text { (mg/L } \\
\text { as N) }\end{array}$ & $\begin{array}{l}\text { Nitro- } \\
\text { gen, } \\
\text { nitrite } \\
\text { dis- } \\
\text { solved } \\
\text { (mg/L } \\
\text { as N) }\end{array}$ & $\begin{array}{l}\text { Nitro- } \\
\text { gen, } \\
\text { nitrate } \\
\text { dis- } \\
\text { solved } \\
\text { (mg/L } \\
\text { as } \mathrm{N} \text { ) }\end{array}$ & $\begin{array}{c}\text { Nitro- } \\
\text { gen, } \\
\text { ammonia } \\
\text { organic } \\
\text { dis- } \\
\text { solved } \\
(\mathrm{mg} / \mathrm{L} \\
\text { as } \mathrm{N} \text { ) }\end{array}$ & $\begin{array}{l}\text { Nitro- } \\
\text { gen, } \\
\mathrm{NO}_{2}+\mathrm{NO}_{3} \\
\text { dis- } \\
\text { solved } \\
\text { (mg/L } \\
\text { as } \mathrm{N} \text { ) }\end{array}$ & $\begin{array}{c}\text { Phos- } \\
\text { phorus, } \\
\text { total } \\
\text { (mg/L } \\
\text { as P) }\end{array}$ & $\begin{array}{l}\text { Phos- } \\
\text { phorus, } \\
\text { dis- } \\
\text { solved } \\
\text { (mg/L } \\
\text { as P) }\end{array}$ & $\begin{array}{c}\text { Phos- } \\
\text { phorus, } \\
\text { ortho, } \\
\text { dis- } \\
\text { solved } \\
\text { (mg/L } \\
\text { as P) }\end{array}$ & $\begin{array}{l}\text { Cadmium } \\
\text { dis- } \\
\text { solved } \\
\text { ( } \mathrm{Hg} / \mathrm{L} \\
\text { as } \mathrm{Cd} \text { ) }\end{array}$ & $\begin{array}{l}\text { Chro- } \\
\text { mium, } \\
\text { dis- } \\
\text { solved } \\
\text { ( } \mu \mathrm{g} / \mathrm{L} \\
\text { as } \mathrm{Cr} \text { ) }\end{array}$ & $\begin{array}{l}\text { Copper, } \\
\text { dis- } \\
\text { solved } \\
\text { ( } \mathrm{Hg} / \mathrm{L} \\
\text { as } \mathrm{Cu} \text { ) }\end{array}$ & $\begin{array}{c}\text { Iron, } \\
\text { dis- } \\
\text { solved } \\
\text { ( } \mu \mathrm{g} / \mathrm{L} \\
\text { as } \mathrm{Fe} \text { ) }\end{array}$ & $\begin{array}{l}\text { Lead, } \\
\text { dis- } \\
\text { solved } \\
\text { ( } \mu \mathrm{g} / \mathrm{L} \\
\text { as } \mathrm{Pb})\end{array}$ & $\begin{array}{l}\text { Manga- } \\
\text { nese, } \\
\text { dis- } \\
\text { solved } \\
\text { ( } \mathrm{Hg} / \mathrm{L} \\
\text { as } \mathrm{Mn} \text { ) }\end{array}$ & $\begin{array}{l}\text { Nickel, } \\
\text { dis- } \\
\text { solved } \\
\text { ( } \mu \mathrm{g} / \mathrm{L} \\
\text { as } \mathrm{Ni})\end{array}$ & $\begin{array}{l}\text { Zinc, } \\
\text { dis- } \\
\text { solved } \\
\text { ( } \mu g / \mathrm{L} \\
\text { as } \mathrm{Zn})\end{array}$ & $\begin{array}{c}\text { Mercury } \\
\text { dis- } \\
\text { solved } \\
\text { ( } \mu g / \mathrm{L} \\
\text { as } \mathrm{Hg} \text { ) }\end{array}$ \\
\hline -- & -- & -- & -- & -- & -- & -- & -- & 10 & $<1$ & 30 & 88,000 & $<1$ & 7,000 & $<1$ & 20 & $<0.1$ \\
\hline $4.70 \underline{a} /$ & $0.120 \mathrm{a} /$ & $0.09 \mathrm{a} /$ & -- & 0.2 ㄴa/ & -- & -- & - & 10 & 10 & $<1$ & 95,000 & 1 & 6,400 & 1 & 33 & $<.1$ \\
\hline 5.40 & $.010^{-}$ & $.42^{-}$ & 5.8 & .43 & 0.010 & 0.010 & $<0.010$ & 8 & 10 & 1 & 97,000 & $i$ & 6,700 & 3 & 29 & $<.1$ \\
\hline 5.30 & .050 & - & 5.1 & $<.10$ & - & .020 & .020 & 9 & 10 & $<1$ & 99,000 & 4 & 6,900 & 3 & 31 & $<.1$ \\
\hline 5.40 & .030 & - & 5.9 & $<.10$ & - & .080 & $<.010$ & 10 & 10 & $<1$ & 96,000 a / & $<1$ & 7,400 & 5 & 27 & $<.1$ \\
\hline 5.70 & .030 & - & 12 & $<.10$ & - & .160 & $<.010$ & 9 & $<10$ & $<1$ & $10,000 \mathrm{a}^{\prime} /$ & 2 & 7,500 & 1 & 40 & $<.1$ \\
\hline 3.70 & $<.010$ & - & -- & $<.10$ & - & .280 & $<.010$ & 9 & 10 & 1 & 120,000 & 1 & 7,500 & 4 & 18 & $<.1$ \\
\hline- & $<.010$ & -- & 12 & .14 & -- & $<.010$ & .010 & - & - & - & - & - & - & -- & - & - \\
\hline 5.40 & $<.010$ & - & 5.7 & $<.10$ & - & .070 & $<.010$ & 7 & 10 & $<1$ & 98,000 & 12 & 7,200 & 3 & 32 & $<.1$ \\
\hline 5.40 & $<.010$ & - & -- & -- & -- & - & - & 8 & $<10$ & 1 & 100,000 & 4 & 7,200 & 2 & 37 & $<.1$ \\
\hline 5.20 & $<.010$ & - & 5.8 & $<.10$ & -- & .020 & $<.010$ & 6 & 10 & $<1$ & 100,000 & $<1$ & 7,200 & 6 & 19 & $<.1$ \\
\hline 5.30 & .030 & - & 5.1 & $<.10$ & - & .050 & $<.010$ & 6 & 10 & 8 & 86,000 & $<1$ & 7,000 & 4 & 22 & $<.1$ \\
\hline 5.20 & .010 & - & 5.4 & $<.10$ & -- & $<.010$ & .010 & 7 & 10 & $<1$ & 82,000 & 4 & 7,100 & 4 & 18 & $<.1$ \\
\hline 4.80 & .030 & -- & 5.3 & $<.10$ & -- & $<.010$ & $<.010$ & 8 & - & 5 & 88,000 & $<1$ & 6,800 & 3 & 40 & $<.1$ \\
\hline 4.90 & .050 & .08 & 5.3 & .13 & -- & $<.010$ & $<.010$ & 8 & 10 & 1 & 79,000 & 2 & 7,300 & 2 & 23 & $<.1$ \\
\hline 5.10 & $<.010$ & -- & -- & $<.10$ & -- & .010 & $<.010$ & 6 & $<10$ & $<1$ & 99,000 & 5 & 6,600 & 6 & 32 & .1 \\
\hline 5.20 & $<.010$ & - & 5.3 & $<.10$ & - & .020 & $<.010$ & 8 & 20 & $<1$ & 87,000 & $<1$ & 6,800 & 1 & 20 & $<.1$ \\
\hline .300 & .040 & 1.2 & -- & 1.2 & -- & -- & -- & 2 & $<1$ & 10 & 8,500 & 9 & 1,600 & 22 & 85 & $<.1$ \\
\hline .180 & $<.010$ & 10 & 1.2 & .78 & - & .030 & $<.010$ & 2 & $<1$ & 4 & 4,800 & 6 & 1,300 & 16 & 48 & $<.1$ \\
\hline .470 & .030 & .64 & .30 & .67 & -- & .020 & $<.010$ & 2 & 10 & 2 & 13,000 & 3 & 2,200 & 20 & 35 & $<.1$ \\
\hline .270 & $<.010$ & - & 1.1 & 1.4 & $<.010$ & $<.010$ & $<.010$ & 2 & 10 & 4 & 13,000 & 6 & 2,100 & 21 & 44 & $<.1$ \\
\hline .210 & .020 & .91 & .30 & .93 & - & .110 & $<.010$ & -- & - & - & 8,600 a / & - & 1,400 a & $1-$ & - & - \\
\hline .270 & .010 & .97 & .60 & .98 & -- & .010 & .010 & 2 & $<10$ & 1 & 10,000 & 7 & 1,600 & 15 & 32 & $<.1$ \\
\hline .770 & $<.010$ & -- & 2.3 & 1.0 & -- & $<.010$ & $<.010$ & $<1$ & $<10$ & 3 & 8,500 & 3 & 1,500 & 16 & 23 & $<.1$ \\
\hline $.140 \mathrm{a} /$ & $<.010$ & -- & .90 & .22 & -- & $<.010$ & $<.010$ & 1 & $<10$ & 2 & 8,100 & 6 & 1,400 & 18 & 26 & .1 \\
\hline .160 & $<.010$ & -- & .40 & 1.0 & -- & $<.010$ & $<.010$ & 2 & $<10$ & 3 & 6,900 & 10 & 1,400 & 14 & 20 & $<.1$ \\
\hline .140 & $<.010$ & - & .80 & .94 & -- & $<.010$ & $<.010$ & 1 & $<10$ & 2 & 8,200 & 2 & 1,500 & 15 & 18 & $<.1$ \\
\hline .140 & $<.010$ & -- & .30 & 1.0 & -- & .020 & $<.010$ & $<1$ & 10 & 2 & 7,000 & 4 & 1,300 & 13 & 16 & $<.1$ \\
\hline .180 & $<.010$ & - & .30 & .86 & - & .040 & $<.010$ & $<1$ & - & - & 3,100 a $/$ & - & 1,400 & - & 17 & -- \\
\hline .160 & $<.010$ & -- & 1.0 & .72 & -- & $<.010$ & $<.010$ & $\langle 1$ & $<10$ & 2 & $6,600^{-}$ & 6 & 1,600 & 18 & 19 & $<.1$ \\
\hline .390 & .030 & .57 & .80 & .60 & -- & $<.010$ & $<.010$ & 2 & -- & 3 & 7,300 & $<1$ & 1,800 & 20 & 25 & $<.1$ \\
\hline .230 & .050 & .79 & .30 & .84 & -- & $<.010$ & $<.010$ & $<1$ & 10 & 2 & 5,500 & 4 & 1,600 & 13 & 18 & $<.1$ \\
\hline .130 & $<.010$ & -- & -- & .53 & -- & $<.010$ & $<.010$ & $<1$ & $<10$ & 2 & 5,000 & 3 & 1,500 & 15 & 19 & $<.1$ \\
\hline .170 & $<.010$ & - & .60 & .62 & -- & $<.010$ & $<.010$ & 1 & 10 & 2 & 5,700 & $<1$ & 1,500 & 13 & 18 & $<.1$ \\
\hline .700 & .050 & -- & 1.0 & $<.10$ & -- & .010 & $<.010$ & $<1$ & $<1$ & 4 & 92 & 2 & 9,700 & 5 & 34 & $<.1$ \\
\hline 3.40 & .080 & .02 & 3.0 & .10 & -- & .190 & .010 & 10 & $<1$ & 30 & 91,000 & $<1$ & 12,000 & 4 & 64 & $<.1$ \\
\hline 3.50 & .030 & .44 & 3.9 & .47 & .030 & .030 & $<.010$ & 8 & 10 & 1 & 99,000 & 1 & 12,000 & 9 & 93 & $<.1$ \\
\hline 3.50 & .030 & .07 & 4.2 & .10 & -- & .100 & .010 & 10 & 10 & $<1$ & 99,000 a $/$ & $<1$ & 12,000 & 6 & 79 & .1 \\
\hline 3.70 & .030 & .07 & 5.1 & .10 & -- & .010 & .040 & 8 & 10 & $<1$ & 100,000 & $<1$ & 11,000 & 6 & 64 & $<.1$ \\
\hline 2.90 & $<.010$ &.$\overline{30}$ & $\begin{array}{l}5.2 \\
5: 1\end{array}$ & $\begin{array}{l}<.10 \\
.33\end{array}$ & $=$ & $\begin{array}{l}.070 \\
.240\end{array}$ & $<.010$ & 9 & $\begin{array}{r}<10 \\
10\end{array}$ & 11 & $\begin{array}{l}100,000 \\
120,000\end{array}$ & $\begin{array}{l}1 \\
10\end{array}$ & $\begin{array}{l}13,000 \\
14,000\end{array}$ & $\begin{array}{l}10 \\
12\end{array}$ & $\begin{array}{l}63 \\
57\end{array}$ & $<.1$ \\
\hline $\begin{array}{l}3.10 \text { a } \\
3.60\end{array}$ & .030 & -3 & 3.8 & $<.10$ & $\overline{-}$ & .030 & $\begin{array}{l}.090 \\
.010\end{array}$ & 7 & $\begin{array}{l}10 \\
10\end{array}$ & $<1$ & 110,000 & 11 & $\begin{array}{l}14,000 \\
15,000\end{array}$ & $\begin{array}{r}12 \\
5\end{array}$ & 41 & $<1$ \\
\hline 3.50 & $<.010$ & -- & 3.9 & $<.10$ & -- & $<.010$ & .020 & 8 & $<10$ & $<1$ & 120,000 & 3 & 14,000 & 5 & 33 & $<.1$ \\
\hline 3.50 & $<.010$ & - & 3.9 & $<.10$ & -- & $<.010$ & $<.010$ & 7 & 10 & 3 & 120,000 & $<1$ & 13,000 & 3 & 21 & $<.1$ \\
\hline 3.80 & .020 & -- & 4.0 & $<.10$ & -- & .010 & $<.010$ & 7 & 10 & 1 & 110,000 & $<1$ & 12,000 & 10 & 14 & $<.1$ \\
\hline-- & -- & -- & -- & -- & -- & -- & - & 8 & $<10$ & $<1$ & 120,000 & 4 & 12,000 & 6 & 6 & $<.1$ \\
\hline 3.60 & .040 & -- & 4.3 & $<.10$ & -- & $<.010$ & $<.010$ & 10 & -- & $<1$ & 140,000 & 1 & 12,000 & 4 & 8 & $<.1$ \\
\hline 3.80 & .110 & .75 & 4.1 & .86 & -- & $<.010$ & .040 & 9 & 10 & $<1$ & 130,000 & 3 & 12,000 & 2 & 9 & .4 \\
\hline 3.80 & .030 & -- & -- & $<.10$ & -- & $<.010$ & $<.010$ & 7 & $<10$ & 1 & 110,000 & 5 & 12,000 & 9 & 7 & $<.1$ \\
\hline 3.70 & $<.010$ & -- & 3.9 & $<.10$ & -- & .120 & .010 & 9 & 20 & $<1$ & 110,000 & $<1$ & 12,000 & 3 & 6 & $<.1$ \\
\hline 1.20 & .030 & .93 & 1.8 & .96 & -- & .010 & .010 & 2 & $<1$ & 2 & $160 \mathrm{a} /$ & 5 & 7,200 & 47 & 93 & $<.1$ \\
\hline 1.40 & $<.010$ & - & 2.2 & .55 & - & .030 & .010 & $<1$ & $<1$ & 1 & 320 & 2 & 11,000 & 5 & 32 & $<.1$ \\
\hline 1.50 & .020 & .56 & 2.3 & .58 & - & $<.010$ & $<.010$ & $<1$ & $<10$ & 2 & 280 & 2 & 12,000 & 5 & 21 & $<.1$ \\
\hline 1.60 & $<.010$ & - & 3.0 & .27 & .020 & .020 & .020 & 1 & 10 & 11 & 470 & 2 & 13,000 & 10 & 27 & .1 \\
\hline 1.60 & .030 & $.3 b$ & 1.9 & .38 & - & .010 & .010 & $<1$ & $<10$ & 1 & 710 & 1 & 13,000 & 6 & 26 & $<.1$ \\
\hline 1.50 & .020 & .26 & 1.8 & .28 & -- & .110 & $<.010$ & $<1$ & 10 & $<1$ & 620 & $<1$ & 13,000 & 5 & 22 & .2 \\
\hline 1.60 & .010 & .38 & 2.8 & .39 & -- & .010 & .010 & $<1$ & $<10$ & $<1$ & 860 & 2 & 12,000 & 1 & 34 & $<.1$ \\
\hline $\begin{array}{l}1.50 \\
1.60 a /\end{array}$ & $\begin{array}{l}<.010 \\
.010\end{array}$ &.$\overline{16}$ & $\begin{array}{l}5.4 \\
2.1\end{array}$ & .28 & $=$ & $\begin{array}{l}.020 \\
: 010\end{array}$ & $<.010$ & $\leq 1$ & $<10$ & 2 & $\begin{array}{l}770 \\
490 \mathrm{a} /\end{array}$ & -4 & $\begin{array}{l}15,000 \\
13,000 \mathrm{a} /\end{array}$ & 15 & 14 & $\therefore 2$ \\
\hline $1.60^{\circ}$ & $<.010$ & - & 1.4 & .11 & -- & .010 & .040 & $<1$ & 10 & 1 & 710 & 7 & 15,000 & 6 & 17 & $<.1$ \\
\hline 1.60 & $<.010$ & - & 2.1 & .17 & -- & $<.010$ & .020 & $<1$ & $<10$ & $<1$ & 780 & 1 & 14,000 & 3 & 38 & $<.1$ \\
\hline 1.60 & $<.010$ & -- & 1.8 & $<.10$ & -- & $<.010$ & .010 & $<1$ & $<10$ & 1 & 1,000 & 1 & 14,000 & 9 & 31 & $<.1$ \\
\hline .790 & .030 & .17 & 1.5 & .20 & -- & .020 & .020 & $<1$ & 10 & 2 & 74 & 2 & 14,000 & 4 & 12 & $<.1$ \\
\hline 1.60 & $<.010$ & - & 2.4 & .51 & -- & $<.010$ & $<.010$ & $<1$ & $<10$ & $<1$ & 920 & 1 & 13,000 & 5 & 13 & $<.1$ \\
\hline 1.50 & .030 & .44 & 2.6 & .47 & -- & $<.010$ & $<.010$ & $<1$ & - & 3 & 590 & $<1$ & 12,000 & 5 & 16 & .6 \\
\hline $\begin{array}{l}1.50 \\
1.40 \mathrm{a} /\end{array}$ & $\begin{array}{l}.060 \\
.010 \mathrm{a} /\end{array}$ & $::_{50 \mathrm{a} /}^{81}$ & 1.6 & $::_{51}^{87} /$ & $=$ & $<.010$ & .010 & $\ll 11$ & $\begin{array}{l}10 \\
10\end{array}$ & $\frac{2}{2}$ & $\begin{array}{l}580 \\
910\end{array}$ & $\begin{array}{l}4 \\
2\end{array}$ & $\begin{array}{l}11,000 \\
10,000\end{array}$ & $\begin{array}{l}4 \\
5\end{array}$ & $\begin{array}{l}16 \\
17\end{array}$ & $\langle: 1$ \\
\hline 60 & $<.010^{-}$ & & 1.5 & .36 & 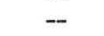 & .040 & .010 & $<1$ & $<10$ & i & 580 & 1 & 11,000 & 5 & 12 & $<.1$ \\
\hline
\end{tabular}


Chemical analyses of ground water for major lons and trace elements [ $\mathrm{LS} / \mathrm{cm}$, microsiemens per centimeter; rg/L, milligrams per liter; $\mathrm{gg} / \mathrm{L}$, micrograms per 11ter; a dash indicates no datal--Continued

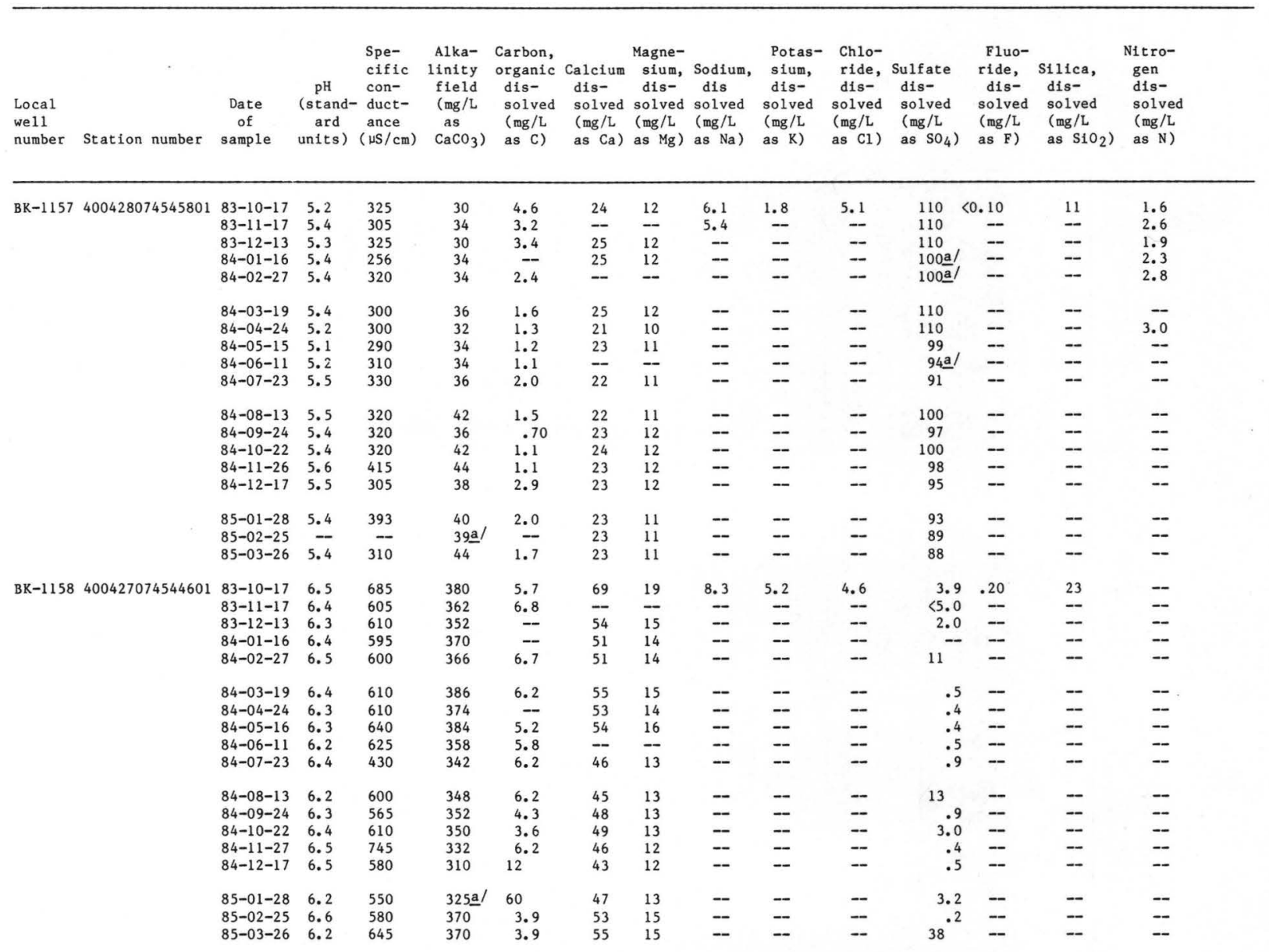




\begin{tabular}{|c|c|c|c|c|c|c|c|c|c|c|c|c|c|c|c|c|}
\hline $\begin{array}{l}\text { Nitro- } \\
\text { gen, } \\
\text { ammonia } \\
\text { dis- } \\
\text { solved } \\
\text { (mg/L } \\
\text { as } \mathrm{N} \text { ) }\end{array}$ & $\begin{array}{l}\text { Nitro- } \\
\text { gen, } \\
\text { nitrite } \\
\text { dis- } \\
\text { solved } \\
\text { (mg/L } \\
\text { as } \mathrm{N} \text { ) }\end{array}$ & $\begin{array}{l}\text { Nitro- } \\
\text { gen, } \\
\text { nitrate } \\
\text { dis- } \\
\text { solved } \\
(\mathrm{mg} / \mathrm{L} \\
\text { as } \mathrm{N} \text { ) }\end{array}$ & $\begin{array}{l}\text { Nitro- } \\
\text { gen, } \\
\text { ammonia + } \\
\text { organic } \\
\text { dis- } \\
\text { solved } \\
\text { (mg/L } \\
\text { as N) }\end{array}$ & $\begin{array}{c}\text { Nitro- } \\
\text { gen, } \\
\mathrm{NO}_{2}+\mathrm{NO}_{3} \\
\text { dis- } \\
\text { solved } \\
(\mathrm{mg} / \mathrm{L} \\
\text { as } \mathrm{N})\end{array}$ & $\begin{array}{c}\text { Phos- } \\
\text { phorus, } \\
\text { total } \\
\text { (mg/L } \\
\text { as P) }\end{array}$ & $\begin{array}{l}\text { Phos- } \\
\text { phorus, } \\
\text { dis- } \\
\text { solved } \\
\text { (mg/L } \\
\text { as P) }\end{array}$ & $\begin{array}{c}\text { Phos- } \\
\text { phorus, } \\
\text { ortho, } \\
\text { dis- } \\
\text { solved } \\
\text { (mg/L } \\
\text { as P) }\end{array}$ & $\begin{array}{l}\text { Cadmium } \\
\text { dis- } \\
\text { solved } \\
\text { ( } \mu \mathrm{g} / \mathrm{L} \\
\text { as } \mathrm{Cd} \text { ) }\end{array}$ & $\begin{array}{l}\text { Chro- } \\
\text { mium, } \\
\text { dis- } \\
\text { solved } \\
(\mu g / \mathrm{L} \\
\text { as } \mathrm{Cr} \text { ) }\end{array}$ & $\begin{array}{l}\text { Copper, } \\
\text { dis- } \\
\text { solved } \\
\text { ( } \mu \mathrm{g} / \mathrm{L} \\
\text { as } \mathrm{Cu} \text { ) }\end{array}$ & $\begin{array}{l}\text { Iron, } \\
\text { dis- } \\
\text { solved } \\
(\mu \mathrm{g} / \mathrm{L} \\
\text { as } \mathrm{Fe})\end{array}$ & $\begin{array}{l}\text { Lead, } \\
\text { dis- } \\
\text { solved } \\
(\mu \mathrm{g} / \mathrm{L} \\
\text { as } \mathrm{Pb})\end{array}$ & $\begin{array}{c}\text { Manga- } \\
\text { nese, } \\
\text { dis- } \\
\text { solved } \\
(\mu \mathrm{g} / \mathrm{L} \\
\text { as Mn) }\end{array}$ & $\begin{array}{c}\text { Nickel, } \\
\text { dis- } \\
\text { solved } \\
\text { ( } \mu \mathrm{g} / \mathrm{L} \\
\text { as } \mathrm{Ni} \text { ) }\end{array}$ & $\begin{array}{l}\text { Zinc, } \\
\text { dis- } \\
\text { solved } \\
\text { ( } \mu \mathrm{g} / \mathrm{L} \\
\text { as } \mathrm{Zn} \text { ) }\end{array}$ & $\begin{array}{c}\text { Mercury } \\
\text { dis- } \\
\text { solved } \\
\text { ( } \mathrm{ug} / \mathrm{L} \\
\text { as } \mathrm{Hg} \text { ) }\end{array}$ \\
\hline 1.10 & 0.030 & 0.21 & 1.4 & 0.24 & -- & 0.010 & $<0.010$ & $<1$ & $<1$ & 2 & 120 & 2 & 13,000 & 38 & 75 & $<0.1$ \\
\hline 1.40 & .010 & .16 & 2.4 & .17 & -- & .010 & .020 & 1 & $<1$ & 1 & 1,400 & 1 & 12,000 & 31 & 64 & $<.1$ \\
\hline 1.50 & .020 & .24 & 1.6 & .26 & -- & $<.010$ & $<.010$ & 2 & $<10$ & 2 & 1,600 & 4 & 13,000 & 33 & 72 & $<.1$ \\
\hline 1.40 & $<.010$ & - & 1.2 & 1.1 & - & $<.010$ & .030 & 1 & 10 & 11 & 2,000 & 1 & 13,000 & 32 & 69 & $<.1$ \\
\hline $\begin{array}{l}1.40 \\
1.60\end{array}$ & .030 & .12 & 2.6 & .15 & - & $<.010$ & $<.010$ & - & - & 11 & 3,700 a / & - & 12,000 a $/$ & 132 & - & -1 \\
\hline 1.50 & .020 & - & 2.2 & $<.10$ & - & .090 & $<.010$ & 1 & 10 & 2 & 2,900 & 4 & 12,000 & 32 & 520 & $<.1$ \\
\hline 1.40 & $<.010$ & -- & 2.9 & .12 & - & $<.010$ & .020 & 1 & $<10$ & 3 & 2,200 & 1 & 12,000 & 40 & 110 & $<.1$ \\
\hline 1.80 & $<.010$ & -- & 3.2 & $<.10$ & -- & $<.010$ & $<.010$ & 2 & $<10$ & 2 & 2,700 & 2 & 13,000 & 26 & 52 & $<.1$ \\
\hline $1.60 \mathrm{a} /$ & .020 & -- & 2.1 & $<.10$ & - & $<.010$ & .020 & -- & - & - & 2,000 a/ & - & 11,000 a $/$ & $1=$ & - & - \\
\hline $1.40^{-}$ & $<.010$ & -- & 1.1 & $<.10$ & - & .020 & .010 & $<1$ & $<10$ & 2 & 2,900 & 10 & 12,000 & 26 & 59 & $<.1$ \\
\hline 1.40 & $<.010$ & - & 1.8 & $<.10$ & - & $<.010$ & .020 & $<1$ & $<10$ & 2 & 2,900 & 1 & 12,000 & 26 & 56 & $<.1$ \\
\hline 1.50 & $<.010$ & -- & 1.6 & $<.10$ & -- & $<.010$ & .010 & 1 & 20 & 5 & 3,400 & $<1$ & 12,000 & 20 & 50 & $<.1$ \\
\hline 1.10 & .030 & .10 & 1.3 & .13 & - & .030 & $<.010$ & $<1$ & 10 & 6 & 3,400 & 2 & 12,000 & 27 & 43 & $<.1$ \\
\hline 1.40 & $<.010$ & - & 1.8 & .15 & -- & $<.010$ & $<.010$ & $<1$ & $<10$ & $<1$ & 3,600 & 2 & 11,000 & 25 & 42 & $<.1$ \\
\hline 1.30 & $<.010$ & - & 2.0 & .14 & - & $<.010$ & $<.010$ & $<1$ & - & 2 & 3,000 & $<1$ & 11,000 & 27 & 44 & $<.1$ \\
\hline 1.50 & .040 & .34 & 1.5 & .38 & - & .010 & $<.010$ & $<1$ & $<10$ & 2 & 4,900 & 4 & 11,000 & 20 & 40 & .1 \\
\hline $1.50^{\mathrm{a} /}$ & .030 a $/$ & $.04 a /$ & - & $<.10$ a $/$ & - & - & 0 & $<1$ & $<10$ & 2 & 4,200 & 4 & 11,000 & 24 & 42 & $i_{0} 1$ \\
\hline 1.60 & $<.010^{-}$ & - & 2.1 & $<.10$ & - & $<.010$ & .020 & $<1$ & $<10$ & 2 & 5,100 & $<1$ & 10,000 & 25 & 38 & .1 \\
\hline 3.10 & .040 & -- & 5.6 & $<.10$ & -- & $<.010$ & $<.010$ & 7 & $<1$ & 1 & 70,000 & 1 & 15,000 & 4 & 23 & $<.1$ \\
\hline 4.80 & .030 & - & 4.6 & $<.10$ & - & .140 & $<.010$ & 7 & $<1$ & 60 & 68,000 & $<1$ & 15,000 & 1 & 58 & $<.1$ \\
\hline $4.10^{\mathrm{a} /}$ & - & -- & - & - & -- & - & - & 8 & $<10$ & 6 & 70,000 & 4 & 15,000 & 2 & 67 & $\ddot{r}_{1}$ \\
\hline 4.30 & .030 & -- & 5.0 & $<.10$ & 0.070 & .070 & .050 & 6 & 10 & 2 & 70,000 & 1 & 14,000 & 4 & 34 & $<.1$ \\
\hline 4.30 & .030 & - & 4.2 & $<.10$ & - & .070 & $<.010$ & $\begin{array}{l}0 \\
6\end{array}$ & 10 & 2 & 77,000 & 3 & 16,000 & 2 & 45 & .1 \\
\hline 4.50 & .030 & .07 & 4.6 & .10 & - & .150 & .010 & 8 & 20 & $<1$ & 80,000 & $<1$ & 16,000 & 1 & 23 & $<.1$ \\
\hline 4.50 & .010 & - & 5.1 & $<.10$ & - & .230 & $<.010$ & 7 & 10 & $<1$ & 84,000 & 3 & 16,000 & 2 & 35 & $<.1$ \\
\hline 3.20 & .010 & .09 & 6.7 & .10 & - & .010 & .010 & 7 & $<10$ & 1 & 86,000 & 1 & 16,000 & 4 & 14 & $<.1$ \\
\hline $4.50 \mathrm{a} /$ & .020 & .52 & 9.9 & .54 & -- & .270 & .110 & -- & - & -- & 77,000 a / & - & 15,000 a / & $1 \quad-$ & - & - \\
\hline 4.10 & .010 & -- & 4.3 & $<.10$ & -- & .280 & $<.010$ & 6 & 10 & $<1$ & $81,000^{-}$ & 10 & $13,000^{-}$ & 3 & 36 & $<.1$ \\
\hline 4.00 & $<.010$ & -- & 3.9 & $<.10$ & - & $<.010$ & .010 & 5 & $<10$ & $<1$ & 79,000 & 3 & 14,000 & $<1$ & 28 & $<.1$ \\
\hline 3.90 & $<.010$ & -- & 4.3 & $<.10$ & -- & .010 & .040 & 5 & 30 & 4 & 86,000 & $<1$ & 14,000 & $<1$ & 28 & $<.1$ \\
\hline $3.10^{\mathrm{a} /}$ & .030 & -- & 4.2 & $<.10$ & - & .100 & $<.010$ & 6 & 20 & 1 & 75,000 & $<1$ & 14,000 & 20 & 19 & $<.1$ \\
\hline 4.00 & $<.010$ & -- & 4.0 & $<.10$ & - & .040 & .020 & 6 & $<10$ & $<1$ & 65,000 & 3 & 13,000 & 3 & 38 & $<.1$ \\
\hline 3.70 & .020 & - & 4.7 & $<.10$ & - & .0400 & $<.010$ & 7 & - & $<1$ & 60,000 & $<1$ & 12,000 & 4 & 40 & $<.1$ \\
\hline 4.10 & .090 & .06 & 4.3 & .15 & - & .040 & .020 & 6 & $<10$ & $<1$ & 71,000 & 2 & 14,000 & 3 & 28 & $<.1$ \\
\hline 4.40 & $<.010$ & - & - & $<.10$ & - & .190 & $<.010$ & 6 & $<10$ & $<1$ & 82,000 & 4 & 16,000 & 4 & 7 & $<.1$ \\
\hline 4.80 & $<.010$ & -- & 5.0 & $<.10$ & -- & .150 & .020 & 6 & $<10$ & $<1$ & 75,000 & $<1$ & 16,000 & 1 & 8 & $<.1$ \\
\hline
\end{tabular}




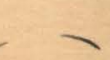

